Marquette University

e-Publications@Marquette

$6-2006$

\title{
Probing Synergism, Antagonism, and Additive Effects in Poly(vinyl Ester) (PVE) Composites with Fire Retardants
}

\author{
Everson Kandare \\ Marquette University \\ Grace Chigwada \\ Marquette University \\ Dongyan Wang \\ Cornell University \\ Charles Wilkie \\ Marquette University, charles.wilkie@marquette.edu \\ Jeanne Hossenlopp \\ Marquette University, jeanne.hossenlopp@marquette.edu
}

Follow this and additional works at: https://epublications.marquette.edu/chem_fac

Part of the Chemistry Commons

\section{Recommended Citation}

Kandare, Everson; Chigwada, Grace; Wang, Dongyan; Wilkie, Charles; and Hossenlopp, Jeanne, "Probing Synergism, Antagonism, and Additive Effects in Poly(vinyl Ester) (PVE) Composites with Fire Retardants" (2006). Chemistry Faculty Research and Publications. 3.

https://epublications.marquette.edu/chem_fac/3 


\title{
Probing Synergism, Antagonism, and Additive Effects in Poly(vinyl Ester) (PVE) Composites with Fire Retardants
}

\author{
Everson Kandare \\ Department of Chemistry, Marquette University \\ Milwaukee, WI \\ Grace Chigwada \\ Department of Chemistry, Marquette University \\ Milwaukee, WI \\ Dongyan Wang \\ Department of Materials Science and Engineering, Cornell \\ University \\ Ithaca, NY
}

Charles A. Wilkie

Department of Chemistry, Marquette University

Milwaukee, WI

Jeanne M. Hossenlopp

Department of Chemistry, Marquette University

Milwaukee, WI 
NOT THE PUBLISHED VERSION; this is the author's final, peer-reviewed manuscript. The published version may be accessed by following the link in the citation at the bottom of the page.

\begin{abstract}
:
Potential fire retardants, including copper hydroxy dodecyl sulfate (CHDS), organically-modified montmorillonite (Cloisite 15A), and resorcinol di-phosphate (RDP), were added to pure poly(vinyl ester) (PVE) individually or in combinations at low concentration formulations. Thermogravimetric analysis and cone calorimetry were used to study the thermal stability and fire performance of the composites. Synergistic, antagonistic, and additive effects were observed depending on the specific formulation. Time to selfsustained combustion is greatly reduced, but the flame extinguishes faster, for the composites containing CHDS alone or in combination with either RDP or Cloisite 15A compared to the virgin polymer. The presence of copper in PVE composites containing additive, CHDS, may be responsible for the enhanced thermal stability and fire performance.
\end{abstract}

Keywords: Poly(vinyl ester), Layered hydroxy salt, Resorcinol di-phosphate, Thermal stability, Fire retardancy.

\title{
1. Introduction
}

Halogen-containing fire retardants (FR) have been used in engineering thermoplastics and epoxy resins to improve their thermal stability and fire performance [1-4]. Despite their demonstrated effectiveness in reducing flammability, the use of halogen-containing fire retardants in commercial plastics is limited because of their corrosivity and potential toxicity. Various non-halogen-containing fire retardants, such as metal oxides, metal hydroxides, metal salts, nitrogen containing, phosphorus containing and cellulose fibers, have been used to enhance the thermal behavior of polymers [5-8].

Aluminum trihydrate (ATH) and magnesium hydroxide (MHD) have been extensively used as fire retardants $[5,6]$. An inherent disadvantage for ATH and MHD is that they are only effective at very high loadings, about 65\%, which can have detrimental effects on the mechanical properties of the polymer. Phosphorus-containing additives have shown excellent thermal stabilization effects on polymers, however, they tend to cause plasticization [9]. It has been postulated that phosphates are oxidized to phosphoric acids during combustion and these acids may alter the degradation pathways of the polymer and promote char formation [6].

Polymer Degradation and Stability, Vol. 91, No. 6 (June 2006): pg. 1209-1218. DOI. This article is (C) Elsevier and permission has been granted for this version to appear in e-Publications@Marquette. Elsevier does not grant permission for this article to be further copied/distributed or hosted elsewhere without the express permission from Elsevier. 
Layered inorganic/organic hybrids, including smectite clays such as montmorillonite (MMT), hectorite (HET), and magadiite (MGH), and synthetic layered hydroxides like layered hydroxy salts (LHSs), layered double hydroxides (LDHs), and hydroxy double salts (HDSs), have recently emerged as potential fire retardants [10-16]. Organicinorganic polymer nanocomposites have superior properties, such as increased thermal stability, heat resistance, mechanical strength and reduced permeability and moisture absorption, compared to the virgin polymer [17].

Fire retardants when used individually are effective in improving some, but not all of the physical properties of the virgin polymers. Combining fire retardant additives can be more effective than using them individually. Formulations with at least two fire retardants may have additive, synergistic, and/or antagonistic effects. An additive effect is the sum of the effects of the two components taken independently. Synergism means that the observed effect is greater than additive, while an antagonistic effect is less than an additive $[18,19]$. In this study the cumulative effect of potential fire retardants, resorcinol di-phosphate, montmorillonite clay (Cloisite 15A), and an LHS, copper hydroxy dodecyl sulfate (CHDS), either individually or in combination, has been investigated. The long-term goal of this work is to develop fire retardant additive combinations that will be effective with respect to multiple fire retardant measures at low concentrations, hence avoiding high fraction loading.

\section{Experimental}

Cloisite 15A, an organically-modified montmorillonite, containing a dimethyl dihydrogenated tallow ammonium cation (hydrogenated tallow is a mixture of $\sim 65 \% \mathrm{C} 18, \sim 30 \% \mathrm{C} 16$, and $\sim 5 \% \mathrm{C} 14$ ) (Southern Clay Products, Inc.), vinyl ester resin, bisphenol-A/novalac epoxy, mass fraction of $67 \%$ in styrene [Derakane 441-400] (Ashland Chemical Co. ); 2-butanone peroxide [BuPO] initiator; cobalt naphthenate catalyst [CoNp] (Aldrich Chemical Co.); sodium dodecyl sulfate (75.0\%) [SDS]; FTIR grade-potassium bromide [KBr] (Alfa Aesar); hydrated copper nitrate (98.9\%) [Cu(N03h-2V2H20] (Fisher Scientific Company); ammonium hydroxide [NH4OH] (EM Science, Merck); and resorcinol di-phosphate [RDP] (Great Lakes Chemical Company) were used as received.

Polymer Degradation and Stability, Vol. 91, No. 6 (June 2006): pg. 1209-1218. DOI. This article is (C) Elsevier and permission has been granted for this version to appear in e-Publications@Marquette. Elsevier does not grant permission for this article to be further copied/distributed or hosted elsewhere without the express permission from Elsevier. 
A layered hydroxy salt (LHS), copper hydroxy nitrate (CHN) was prepared via a standard literature method [20]. Copper (II) nitrate (100 g; $0.430 \mathrm{~mol}$ ) was added to $1 \mathrm{~L}$ of distilled water and the $\mathrm{pH}$ of the resultant solution was adjusted to $8.0 \pm 0.1$ by the addition of aqueous ammonia. The dispersion was aged for $24 \mathrm{~h}$ after which the precipitate was filtered off, washed, and dried. Dodecyl sulfate anions were exchanged for the $\mathrm{NO} 3$ anions in $\mathrm{CHN}$ by mixing the dried $\mathrm{CHN}$ precursor material with $0.2 \mathrm{M}$ solution of sodium dodecyl sulfate. In an anionic exchange reaction, 109 of CHN was mixed with $500 \mathrm{~mL}$ of the exchange solution and shaken frequently for $48 \mathrm{~h}$. The supernatant was decanted and replaced with a fresh sodium dodecyl sulfate solution for another $48 \mathrm{~h}$, after which the exchanged product, copper hydroxy dodecyl sulfate (CHDS) was recovered by filtration, washed, and dried.

Vinyl ester composites ( $\sim 120 \mathrm{~g}$ ) were prepared at room temperature by mixing the resin with fire retardants using a mechanical stirrer for $3 \mathrm{~h}$. The initiator, BuPO (1.3\%), was added followed by addition of catalyst, CoNp (0.3\%), and the mixture was stirred for a few minutes to achieve homogeneity. Pure PVE was loaded to afford $n \%$ fraction of the additives, CHDS, RDP, or Cloisite $15 \mathrm{~A}$ within the polymer matrix, yielding composites identified as PVE/CHDS- $n$, PVE/RDP- $n$, or PVE/15A- $n$, respectively. Composites with $a \%$ CHDS and $b \%$ RDP were prepared and are identified as PVE/CHDS/RDP-a/b. Similarly, composites with both $a \%$ CHDS and $c \%$ Cloisite 15A were prepared, and are identified as PVE/CHDS/15A-a/c. Percent loadings were determined from the final mass of the composite, assuming no loss of the additives during the preparation process. Approximately $30 \mathrm{~g}$ of samples were rapidly transferred into pre-formed $10 \mathrm{~cm} \times 10 \mathrm{~cm} \times 2 \mathrm{~mm}$ aluminum dishes making platelets of uniform thickness for cone calorimetry analysis. Flat samples $\sim 1$ $\mathrm{mm}$ thickness were prepared for X-ray diffraction analysis (XRD). Samples were cured overnight at room temperature and post cured at $80{ }^{\circ} \mathrm{C}$ for $12 \mathrm{~h}$.

X-ray diffraction patterns of the synthesized layered materials were obtained from a 2 circle Rikagu powder diffractometer operating in the parafocusing Bragg-Brentano configuration, with a $1 / 20$ divergence slit, $1 / 20$ scatter slit, $0.15 \mathrm{~mm}$ receiving slit, $0.15 \mathrm{~mm}$ monochromator receiving slit using $\mathrm{Cu} \mathrm{Ka.}(\lambda=1.54 \AA)$ radiation

Polymer Degradation and Stability, Vol. 91, No. 6 (June 2006): pg. 1209-1218. DOI. This article is (C) Elsevier and permission has been granted for this version to appear in e-Publications@Marquette. Elsevier does not grant permission for this article to be further copied/distributed or hosted elsewhere without the express permission from Elsevier. 
source operated at $50 \mathrm{kV}$ and $20 \mathrm{~mA}$, with data acquisition in $2 \theta$ steps of 0.072 per $20 \mathrm{~s}$. Powdered samples were mounted on quartz slides using $10 \%$ (v/v) GE 7031 epoxy in ethanol after it was found that the epoxy did not perturb the observed peak patterns. Polymer composite samples were mounted onto vertically oriented sample holders for XRD analysis. XRD peaks used to determine d-spacing were fit to pseudoVoight functions stripping off the $\mathrm{Cu} \mathrm{Ka2}$ contribution using XFIT [21]. Basal spacings, $d$, of the synthesized clays and polymer composites were obtained using Bragg equation; $\lambda=2 d \sin \theta$, averaging $00 /(I=$ 1-3) reflections were possible. Assignments of phases of known copper-containing species were made using the powder diffraction database [22].

Fourier transform infrared (FTIR) spectra of the solid materials and composites were obtained using the $\mathrm{KBr}$ method on a Nicolet Magna-IR 560 spectrometer operated at $1 \mathrm{~cm}-1$ resolution in the 400$4000 \mathrm{~cm}-1$ region. Thermogravimetric analysis (TGA) and differential thermal analysis (DTA) were performed on an SDT 2960 simultaneous DTA-TGA instrument from 50 to $650^{\circ} \mathrm{C}$ in N2 using a ramp rate of 20 ${ }^{\circ} \mathrm{C} / \mathrm{min}$ with sample sizes in the range of $21 \pm 1 \mathrm{mg}$. All TGA experiments were performed in triplicate; the reproducibility in the amount of nonvolatile residue is $\pm 2 \%$ while the temperature is generally reproducible to $\pm 3{ }^{\circ} \mathrm{C}$. Samples were analyzed by cone calorimetry on an Atlas Cone 2 instrument at an incident flux of 35 $\mathrm{kW} / \mathrm{m} 2$ with a cone shaped heater; the spark was continuous until the sample ignited. All samples were run in triplicate and the average value, and standard deviation, is reported; results from the cone calorimeter are generally considered to be reproducible to $\pm 10 \%$ [23]. Bright field transmission electron microscopy (TEM) images were collected at $60 \mathrm{kV}$ using a Zeiss 10c electron microscope.

\section{Results and Discussion}

\subsection{X-ray diffraction}

X-ray diffraction (XRD) is commonly used to monitor the structural changes of layered inorganic/organic hybrids when they are incorporated into a polymer matrix. XRD patterns for the additive, copper hydroxy dodecyl sulfate (CHDS) and composites PVE/CHDS-10 and PVE/CHDSIRDP-5/5 are shown in Fig. 1A. Two phases with basal

Polymer Degradation and Stability, Vol. 91, No. 6 (June 2006): pg. 1209-1218. DOI. This article is (C) Elsevier and permission has been granted for this version to appear in e-Publications@Marquette. Elsevier does not grant permission for this article to be further copied/distributed or hosted elsewhere without the express permission from Elsevier. 
spacings, $d$, of $25.9 \pm 0.9 \AA$ (filled triangles) and $39.2 \pm 0.2 \AA$ (filled circles) are observed for CHDS. Possible orientations of the dodecyl sulfate anions in the interlayer space relative to the metal hydroxide sheets have been described elsewhere [24]. Peaks marked with filled triangles represent the monolayer CHDS phase while the phase marked with filled circles represent the bilayer phase. The samples were partially exchanged as evident from reflections marked in asterisks due to the precursor, copper hydroxy nitrate (CHN) (PDF\# 14-687) [22] as shown in trace a of Fig. $1 \mathrm{~A}$.

The XRD pattern of PVE loaded with 10\% CHDS, PVE/CHDS-10, is shown in trace $b$ of Fig. $1 \mathrm{~A}$. Basal reflections due to the bilayer phase in CHDS ( $d=39.2 \AA$ ) disappeared suggesting possible exfoliation or intercalation. Partial interdigitation and/or lack of overlapping dodecyl sulfate anions in the bilayer phase leaves open spaces within the galleries into which monomer and/or polymer chains can be accommodated. This would result in expanded basal spacing corresponding to a reduction in $2 \theta$ values to magnitudes beyond the detection limit of the wide-angle $X$-ray diffractometer used. No shifts in $2 \theta$ positions were observed for either the monolayer phase $(d=$ $25.9 \AA$ ) or the $\mathrm{CHN}$ phase; suggesting no intercalation of monomer or polymer chains into their galleries. When PVE is loaded with 5\% CHDS and 5\% RDP, PVE/CHDS/RDP-5/5, the bilayer phase reflections disappear while the monolayer phase basal reflections of CHDS are depleted in intensity relative to the $\mathrm{CHN}$ phase as seen in trace $\mathrm{c}$ of Fig. 1A. The addition of RDP thus appears to result in additional intercalation or exfoliation of the CHDS phase when both additives are incorporated into the polymer.

Fig. 1B shows the XRD patterns of the organically-modified montmorillonite clay (Cloisite 15A), PVE/15A-10, and PVE/CHDS/15A$5 / 5$. Basal reflections at $2 \theta$ values of 2.4 and $4.7^{\circ}$ corresponding to an average $d$-spacing of $37.1 \pm 0.6 \AA$ are seen for Cloisite $15 \mathrm{~A}$ marked with open diamonds. No apparent shift in $2 \theta$ peak positions is seen when Cloisite $15 \mathrm{~A}$ is loaded at $10 \%$. Both the Cloisite $15 \mathrm{~A}$ and the CHDS monolayer phases are seen in the XRD pattern of PVE/CHDS/15A-5/5 (Fig. 1B, trace c). The combination of CHDS and Cloisite 15A does not promote formation of exfoliated and/or intercalated nanocomposites. However, the bilayer phase of the CHDS

Polymer Degradation and Stability, Vol. 91, No. 6 (June 2006): pg. 1209-1218. DOI. This article is (C) Elsevier and permission has been granted for this version to appear in e-Publications@Marquette. Elsevier does not grant permission for this article to be further copied/distributed or hosted elsewhere without the express permission from Elsevier. 
disappeared as seen with CHDS alone suggesting exfoliation and/or intercalation of this phase.

Transmission electron microscopy (TEM) is an important technique commonly used to investigate the morphology of the composites. Fig. 2 shows TEM images for PVE/CHDS/RDP-5/5 sample at both low and high magnifications. Low magnification TEM images provide information about the nano-dispersion while high magnification images indicate whether exfoliation and/or intercalation has been achieved. The low magnification image shown in Fig. 2 (left) is consistent with the formation of a microcomposite; showing fairly well-distributed inorganic/organic material at the micrometer level, within the polymer matrix. The high magnification TEM image shown in Fig. 2 (right) suggests partial exfoliation of the CHDS consistent with the observed intensity reduction of the monolayer CHDS phase relative to $\mathrm{CHN}$ and disappearance of the bilayer CHDS phase in PVE/CHDS/RDP-5/5.

\subsection{Thermogravimetric analysis (TGA)}

Thermogravimetric analysis was carried out on samples of pure PVE and PVE containing fire retardants, CHDS, RDP, and Cloisite 15A both individually and in combination. Fig. 3A shows TGA curves for pure PVE, PVE/CHDS-10, PVE/RDP-10, and PVE/CHDS/RDP-5/5 while Fig. 3B shows the derivatives of these curves. Independent or concomitant addition of CHDS and RDP to the polymer matrix leads to a significant reduction in the onset degradation temperature of the polymer composites, measured as the temperature at which $10 \%$ mass loss occurs, $T_{10}$. Even though PVE/CHDS-10 loses more mass at low temperatures, as seen in the mass difference curves (mass \% of PVE composites minus mass \% of pure PVE at the same temperature) shown in Fig. 4A, its thermal degradation profile is similar to that of pure PVE at higher degradation temperatures. From the TGA curves shown in Fig. 3A, PVE/RDP-10 is the least stable in the temperature range of $350-460{ }^{\circ} \mathrm{C}$. The thermal stability of PVE/CHDS/RDP-S/S is significantly higher than that of PVE/RDP-10; there is a beneficial additive effect from replacing some of the RDP by CHDS. However, no synergistic effects are obvious for PVE/CHDSIRDP-5/5 from TGA analysis as evaluated by $T_{10}, T_{50}$ (temperature at which $50 \%$ mass loss occurs), $T_{\max }$ (the temperature of maximum degradation rate) and the

Polymer Degradation and Stability, Vol. 91, No. 6 (June 2006): pg. 1209-1218. DOI. This article is (C) Elsevier and permission has been granted for this version to appear in e-Publications@Marquette. Elsevier does not grant permission for this article to be further copied/distributed or hosted elsewhere without the express permission from Elsevier. 
amount of char formed. These TGA results are summarized in Table 1. Notably, the char yields in the presence of the RDP and/or CHDS are higher than for pure PVE, suggesting possible condensed phase roles for these additives. Differential thennogravimetric analysis (DTA) curves for pure PVE, PVE/CHDS-10, PVE/RDP-10, and PVE/CHDS/RDP$5 / 5$ are shown in Fig. 4B. The DTA curves of the composites are significantly different from those of pure PVE, suggesting a different degradation pathway.

Fig. 5A shows TGA curves of pure PVE, PVE/CHDS-15, PVE/RDP15, and PVE/CHDS/RDP-5/10 while Fig. 5B shows the corresponding derivatives (DTG) of these curves. Increasing the mass fraction of CHDS and/or RDP from 10 to $15 \%$ did not improve the thermal stability of the polymer, in fact further reductions in $T_{10}, T_{50}, T_{\max }$, and generally in char formation are seen. However, an adjuvant effect [19] in char formation was observed for the PVE/CHDS/RDP-5/10 system as seen in the mass difference curves shown in Fig. 6A where the PVE/CHDS/RDP-5/10 formulation results in higher final char yield than either of the individual compounds at $15 \%$. The thermal degradation profile for PVE/CHDS/RDP-5/10 at higher degradation stages is similar to that of PVE/RDP-15 with comparable $T_{50}$ and $T_{\max }$ values. The DTA curves of the PYE composites, presented in Fig. 6B, are significantly different from those of pure PYE, again suggesting a change in the degradation mechanism. There is an additional advantage of replacing some RDP with CHDS in terms of char formation.

Fig. 7A shows the TGA curves of pure PYE and its composites prepared from loading fire retardants CHDS and Cloisite 15A either individually or in combination at $10 \%$. The corresponding derivatives of these TGA curves are shown in Fig. 7B. $T_{10}$ values are significantly reduced for these composites, compared to pure PVE, suggesting a reduction in thermal stability of PYE composites in the low temperature regime. However, the thermal degradation profile of pure PYE at higher temperatures is similar to those of CHDS and/or Cloisite 15A composites. As seen in Table 1 the parameters used to evaluate thermal stability at higher temperatures, $T_{50}$ and $T_{\max }$, are comparable. A significant increment in char formation is observed for the composites compared to the virgin polymer.

Polymer Degradation and Stability, Vol. 91, No. 6 (June 2006): pg. 1209-1218. DOI. This article is (C) Elsevier and permission has been granted for this version to appear in e-Publications@Marquette. Elsevier does not grant permission for this article to be further copied/distributed or hosted elsewhere without the express permission from Elsevier. 
As shown in the mass difference curves, Fig. 8A, the combination of 5\% CHDS and 5\% Cloisite 15A destabilizes the composite at lower temperatures but results in enhanced char formation, compared with Cloisite 15A alone. DTA curves for PVE and its composites are shown in Fig. 8B. Addition of Cloisite 15A alone does not significantly change the degradation pathway of PVE. DTA curves for pure PVE and PVE/15A-10 are similar with the exception that the endothermic peak at around $450^{\circ} \mathrm{C}$ is broader for the later. PVE/CHDS/15A-5/5 shows a comparable profile, with small exothermic peaks between 250 and $400^{\circ} \mathrm{C}$, which may be due to the thermal degradation of organic moieties contained within the galleries of the layered materials.

In order to investigate the variation of thermal stability with percent additives, CHDS and Cloisite 15A cumulative mass fractions were increased from 10 to $15 \%$. The TGA curves and their corresponding derivatives for pure PVE and its composites are shown in Fig. 9A and B, respectively. Significant reductions in $T_{10}$ are noted, suggesting a destabilization effect in the low temperature region. However, the degradation threshold temperatures at further stages of thermal decomposition, as measured by $T_{50}$ and $T_{\max }$, are comparable to those of the virgin polymer. Noteworthy increments in char formation are seen for the composites relative to the pure polymer. Unlike combinations of CHDS and RDP, the amount of char formed using CHDS and Cloisite 15A independently is not different from the char obtained when these two additives are combined. This is clearly illustrated in the mass difference curves shown in Fig. 10A. The DTA curves for pure PVE and its CHDS and/or Cloisite 15A composites are shown in Fig. 10B. Apart from exothermic processes seen in the DTA profiles for PVE/CHDS/15A-5/10 and PVE/CHDS-15, and the reduction in magnitude of their respective endothermic peaks at about $450{ }^{\circ} \mathrm{C}$, there are no other obvious differences when compared to that of the virgin polymer, suggesting no major changes in the degradation pathway.

Also shown in Table 1 are the expected char\% if the residues were additive, based on the residue obtained individually from pure PVE, CHDS, RDP, and Cloisite 15A. The fact that the observed residue is higher than the calculated demonstrates the effectiveness of these fire retardant additives in char formation. These fire retardants

Polymer Degradation and Stability, Vol. 91, No. 6 (June 2006): pg. 1209-1218. DOI. This article is (C) Elsevier and permission has been granted for this version to appear in e-Publications@Marquette. Elsevier does not grant permission for this article to be further copied/distributed or hosted elsewhere without the express permission from Elsevier. 
generally destabilize the polymer at lower temperatures, however, there is a compensatory stabilization effect as indicated by the formation of char at yields higher than expected. Catalytic char induction and condensed or vapor phase action of phosphorus are implicated in cases where RDP is used as an additive alone [25]. When RDP is used in combination with a montmorillonite-based clay, Cloisite $15 \mathrm{~A}$, the latter can react with acid phosphates to form active carbonization catalysts leading to the formation of char. The acids can also form a molten viscous surface layer protecting the polymer substrate from flame, heat and oxygen. The enhanced char yields observed when RDP is combined with CHDS may be due to the reaction of water with phosphates to form acid phosphates which have been hypothesized to promote char formation [25]. The role of CHDS may be to provide water via either dehydroxylation of the copper hydroxide layers and/or combustion of the dodecyl sulfate.

\subsection{Cone calorimetry}

Cone calorimetry can be used to evaluate and predict the behavior of polymeric materials in real fires. The parameters obtained from this analysis include the heat release rate and especially its peak value (PHRR); total heat release (THR); time to self-sustained combustion (TSC); average mass loss rate (AMLR); average specific extinction area (ASEA) (a measure of smoke); and char yield (CY). Ideally, a decrease in the peak heat release rate, total heat released and the mass loss rate is desired along with an increase in char and time to sustained combustion.

Heat release rate (HRR) curves for pure PVE, PVE/CHDS-10, PVE/RDP-10, and PVE/CHDS/RDP-5/5 at a flux of $35 \mathrm{~kW} / \mathrm{m}^{2}$ are shown in Fig. 11A. The addition of $10 \%$ CHDS alone or a combination of $5 \%$ CHDS and 5\% RDP lowers the time to sustained ignition of the composites relative to the virgin polymer but the HRR curves for the composites show that the evolution of heat is spread over a narrow range of the combustion time. Polymer composites containing CHDS start to bum earlier but they extinguish much faster than the pristine PVE. Similar patterns are seen when Cloisite $15 \mathrm{~A}$ is used in combination with CHDS, as shown in the HRR curve for PVE/CHDS/15A-5/5, Fig. 11B. RDP and Cloisite 15A PVE composites bum over a wider time range.

Polymer Degradation and Stability, Vol. 91, No. 6 (June 2006): pg. 1209-1218. DOI. This article is (C) Elsevier and permission has been granted for this version to appear in e-Publications@ Marquette. Elsevier does not grant permission for this article to be further copied/distributed or hosted elsewhere without the express permission from Elsevier. 
Fig. 12A shows the variation of percent reduction in total heat release with percent fire retardant additive for all the composites under investigation. Significant reductions, greater than $20 \%$, in the total heat released are observed when PVE is loaded with RDP alone. This is not uncommon, as PVE composites containing phosphorusbased fire retardants have been shown to have lower THRs but a wider heat release distribution profile [2]. CHDS when used alone gives the largest reduction in THR, 27\%, at $10 \%$ loading. Combination of CHDS and RDP resulted in an additive effect for the PVE/CHDS/RDP-5/10 formulation. PVE/CHDS- 5 gives $18 \%$ reduction and PVE/RDP-10 gives $31 \%$ reduction in THR while the PVE/CHDSI RDP-5/10 formulation results in $47 \%$, an additive effect within the limits of experimental uncertainty. An antagonistic effect was observed for the PVE/CHDS/RDP-5/5 composite. PVE/CHDS- 5 gives a reduction of $18 \%$ and PVE/RDP-5 gives a reduction of $25 \%$ in THR while the PVE/CHDS/RDP-5/5 formulation gives $22 \%$, an antagonistic effect. Cloisite 15A alone has no effect on the THR suggesting that the polymeric material completely bums. No significant improvement was seen in percent reduction in THR when CHDS was used in combination with Cloisite 15A.

PHRR percent reductions of $>30 \%$ were observed for PVE/RDP composites even at 5\% loading. RDP is effective in reducing PHRR, however, an antagonistic effect is seen when it is combined with CHDS. There is very little or no reduction in PHRR for PVE/CHDS-10 and PVE/CHDS/RDP-5/5, as shown in Fig. 12B. The CHDS additive shows a $38 \%$ reduction in PHRR at $15 \%$, however, the same composition gave the lowest improvement in THR. Synergism is clearly seen for the PVE/CHDS/I5A-5/5 system, where the percent reduction in PHRR is more than additive. PVE/CHDS- 5 gives a reduction of $6 \%$ and PVE/15A-5 gives a reduction of $7 \%$ in PHRR while the PVE/CHDS/15A-5/5 formulation gives $20 \%$, a synergistic effect. Table 2 gives a summary of the results obtained for PVE and its composites with different additive loadings.

The experimentally obtained reductions in THR are significantly larger than the calculated values, suggesting that THR reductions are not a result of replacing some fraction of PVE (THR $=79 \mathrm{MJ} / \mathrm{m}^{2}$ for 30 g) with an equal amount of the fire retardant additives, CHDS, RDP, or Cloisite 15A with lower THR values for $30 \mathrm{~g}$ of samples, 51, 55, and 52

Polymer Degradation and Stability, Vol. 91, No. 6 (June 2006): pg. 1209-1218. DOI. This article is (C) Elsevier and permission has been granted for this version to appear in e-Publications@Marquette. Elsevier does not grant permission for this article to be further copied/distributed or hosted elsewhere without the express permission from Elsevier. 
$\mathrm{MJ} / \mathrm{m}^{2}$, respectively. This is clear evidence that these fire retardant additives are effective in reducing the flammability of the PVE. Notable increments in char formation for the composite materials relative to the pure polymer are seen and the values are also reported in Table 2. The improvement in fire retardancy is shown by positive changes in two parameters, the reduction in the THR and the increase in the char remaining after combustion.

Significant reductions in the amount of smoke as measured by the ASEA for PVE/CHDS/RDP formulations as compared to PVE/RDP composites at the same cumulative loadings are observed. This is consistent with the work performed by Pike and coworkers [26], who reported that low-valent metal additives prevent cracking of hydrocarbon char at high temperature, suggesting that less volatile molecules are produced, reducing the smoke and increasing the char. No significant reductions were seen in the average mass loss rate for all composites with the exception of PVE/CHDS-15, PVE/15A, and $\mathrm{PVE} / \mathrm{CHDS} / \mathrm{I5A}-5 / 10$. This suggests that in all the other cases the decomposition rate is slightly or not at all affected by the presence of the additives within the polymer matrix. Future work will focus on developing a high throughput screening technique to find the mass fraction that would give improvements in more than one parameter.

In order to explore the mechanism of fire retardancy in coppercontaining formulations, the composite, PVE/CHDS/RDP-5/5 was heated in the TGA at $20^{\circ} \mathrm{C} / \mathrm{min}$. Samples were extracted at different times in the heating profile and the resulting residues were analyzed by XRD. The results are shown in Fig. 13. The XRD pattern of PYE/CHDS/RDP- $5 / 5$ from the TGA residue at $250^{\circ} \mathrm{C}$ reveals the presence of the CHN phase (PDF\# 14-687) [22]. The CHDS and Cloisite 15A phases are not evident from the XRD pattern at this temperature, suggesting their collapse and/or existence in an amorphous state. $\mathrm{CU}_{2} \mathrm{O}$ (PDF\# 35-1091) [22] and metallic copper (PDF\# 4-836) [22] are seen in the XRD pattern of the residue collected at $300{ }^{\circ} \mathrm{C}$. Of particular interest is the disappearance of $\mathrm{Cu}_{2} \mathrm{O}$ phase in the $400{ }^{\circ} \mathrm{C}$ trace with the formation of metallic copper and a second phase with a sharp peak at $28.4^{\circ}$ that could not be identified. Disproportionation of $\mathrm{Cu}(\mathrm{I})$ may lead to the formation of metallic copper, $\mathrm{Cu}(0)$ and $\mathrm{Cu}(\mathrm{II})$ as illustrated by the equation; $2 \mathrm{Cu}(\mathrm{I}) \rightarrow \mathrm{Cu}$

Polymer Degradation and Stability, Vol. 91, No. 6 (June 2006): pg. 1209-1218. DOI. This article is (C) Elsevier and permission has been granted for this version to appear in e-Publications@Marquette. Elsevier does not grant permission for this article to be further copied/distributed or hosted elsewhere without the express permission from Elsevier. 
(0) + Cu (II). This suggests that the unidentified phase may be a $\mathrm{Cu}$ (II) containing compound.

The presence of metallic copper as shown in the XRD patterns of the TGA residues for PVE/CHDS/RDP-5/5 at 350, 400, and $450{ }^{\circ} \mathrm{C}$ may prevent depolymerization of PVE through reductive coupling, thus promoting char formation. $\mathrm{Cu}$ (II) readily reduces to $\mathrm{Cu}$ (I) or $\mathrm{Cu}(0)$ [27]; the stabilization effect observed stems from the ability Cu (II) to form zero-or low-valent metal species upon pyrolysis. Interestingly, the evolution of copper species with temperature for PVE/CHDS/RDP$5 / 5$ is similar to the pattern seen with PVE/CHDS-10, suggesting that RDP has little or no effect on the reaction catalyzed by metallic copper. The copper reaction is proposed to be reductive coupling following the abstraction of pendant hydroxyl groups by metallic copper [24]. Reductive coupling promotes intermolecular cross-linking of conjugated polyenes produced during the initial stages of degradation otherwise these polyenes could undergo cyclization reactions leading to the formation of benzene and other aromatics, which would burn to produce heat and smoke. A similar stabilizing effect on the thermal degradation of poly(vinyl chloride) (PVC) using copper (I) salts ( $\mathrm{CuCl}$, $\mathrm{CuBr}$, and $\mathrm{CuI}$ ) and $\mathrm{Cu}$ (II) complexes has been reported $[26,28]$.

The XRD patterns of the TGA residue at the indicated temperatures for PVE/CHDS/RDP-5/5 do not show any evidence of polycrystalline $\mathrm{Cu}(\mathrm{OH})_{2}$, the expected product of hydroxyl abstraction from polymer chains. The absence of $\mathrm{Cu}(\mathrm{OH})_{2}$ reflections in the XRD patterns of the TGA residue suggests it may exist in an amorphous phase. In the case of CHDS alone, FTIR spectra of the samples heated to 350 and $400{ }^{\circ} \mathrm{C}$ [24] exhibited peaks at $3740 \mathrm{~cm}-1$ consistent with non-hydrogen bonded $\mathrm{Cu}-\mathrm{OH}$ groups [29]. However, FTIR spectra of the TGA residues of PVE/CHDS/RDP-5/5 at various temperatures shown in Fig. 14 do not exhibit this feature. This may suggest interaction between RDP and CHDS additives or intermediates formed during decomposition. Further characterization of this system will be the subject of future work.

LHSs and smectite clays act as fire retardants through several modes of action that include: (i) dilution of flammable volatiles by noncombustible gases $\left(\mathrm{H}_{2} \mathrm{O}\right.$ and $\left.\mathrm{CO}_{2}\right)$ generated from the thermal degradation of the additives, (ii) the formation of a stable char layer

Polymer Degradation and Stability, Vol. 91, No. 6 (June 2006): pg. 1209-1218. DOI. This article is (C) Elsevier and permission has been granted for this version to appear in e-Publications@Marquette. Elsevier does not grant permission for this article to be further copied/distributed or hosted elsewhere without the express permission from Elsevier. 
over the polymer substrate reducing diffusion of combustible matter (mass transport) and/or energy transfer, (iii) the endothermic decomposition of the layered material resulting in release of $\mathrm{H}_{2} \mathrm{O}$ and absorption of heat from the burner polymer, hence retarding thermooxidative degradation. With RDP, phosphoric acid produced during pyrolysis forms a protective layer above the polymer substrate preventing volatilization of fuels and oxygen penetration to the condensed phase [30].

\section{Conclusion}

The thermal and combustion behaviors of PVE formulations containing CHDS, RDP, and Cloisite 15A, individually or in combination, have been studied using both cone calorimetry and TGA. Significant increments in TGA char formation, up to $260 \%$, in some cases were observed when the fire retardants were used individually or in combination. These notable increments in char formation suggest the effectiveness of these additives as potential fire retardants. No synergistic effect as measured by char yields are apparent for formulations where CHDS was mixed with RDP or Cloisite 15A either from cone calorimetry or the TGA residue. Antagonistic effects in PHRR were observed in all cases except for the PVE/CHDS/15A-5/5 composite; there is no improvement in the time to self-sustained combustion. PVE/CHDS/RDP-5/10 gave a higher percent reduction in THR ( 47\%) when compared with composites, PVE/CHDS-15 ( 14\%), PEV/RDP-15 ( 33\%) or PVE/15A-15 ( 9\%). Replacing some RDP by CHDS enhances thermal stability in the system described above as evaluated by THR.

\section{Acknowledgements}

We thank the Office of Naval Research (CAW, grant number NOOO 14-03-1-0 172) for financial assistance and $M$. Bartelt and J. Collins for technical support of the X-ray diffractometer.

\section{References}

1. Georlette P, Simons J, Costa L. In: Grand AF, Wilkie CA, editors. Fire retardancy of polymeric materials. Marcel Dekker, Inc.; 2000. p.24584.

Polymer Degradation and Stability, Vol. 91, No. 6 (June 2006): pg. 1209-1218. DOI. This article is (C) Elsevier and permission has been granted for this version to appear in e-Publications@Marquette. Elsevier does not grant permission for this article to be further copied/distributed or hosted elsewhere without the express permission from Elsevier. 
NOT THE PUBLISHED VERSION; this is the author's final, peer-reviewed manuscript. The published version may be accessed by following the link in the citation at the bottom of the page.

2. Chigwada G, Jash P, Jiang DD, Wilkie CA. Polym Degrad Stab 2005;89:85.

3. Jakab E, Uddin MdA, Bhaskar T, Sakata Y. J Anal Appl Pyrol 2003; 6869:83.

4. Cusak PA, Heer MS, Monk AW. Polym Degrad Stab 1991;32:177.

5. Kicko-Walczak E. Polimery 1999;44:724.

6. Weil ED, Kim HK. Flame retardant unsaturated resins-an overview and new developments. Eighth annual BCC conference on advances in flame retardancy of polymeric materials, Stamford, Connecticut; 1997.

7. Liang H, Shi W. Polym Degrad Stab 2004;84:525.

8. Zheng X, Wilkie CA. Polym Degrad Stab 2003;81:539.

9. Levchik SV, Bright DA, Dashevsky S, Moy P. In: AI-Malaika S, Golovoy A, Wilkie CA, editors. Specialty polymer additives: principles and applications. London: Blackwell Scientific; 2001. p. 259-69.

10. Bubniak GA, Schreiner WH, Mattoso N, Wypych F. Langmuir 2002;18:5967.

11. Leroux F, Besse J. Chern Mater 2001;13:3507.

12. Chen W, Qu B. Chern Mater 2003;15:3208.

13. Messersmith BP, Stupp S1. Chern Mater 1995; 7:454.

14. Kandare E, Hall D, Jiang DD, Hossenlopp JM. In: Wilkie CA, Nelson GL, editors. Fire and polymers IV: materials and concepts for hazard prevention. ACS symposium series. Oxford University Press, in press.

15. Kandare E, Hossenlopp JM. Polym Mater 2005;16:215.

16. Kandare E, Deng H, Wang D, Hossenlopp JM. Polym Adv Technol, in press.

17. Alexandre M, Dubois P. Mater Sci Eng 2000;R28: I.

18. Weil ED. In: Kuryla WC, Papa AJ, editors. Flame retardancy of polymeric materials. Marcel Dekker, Inc.; 1975. p. 185-243.

19. Weil ED. In: Grand AF, Wilkie CA, editors. Fire retardancy of polymeric materials. Marcel Dekker, Inc.; 2000. p. 115-45.

Polymer Degradation and Stability, Vol. 91, No. 6 (June 2006): pg. 1209-1218. DOI. This article is (C) Elsevier and permission has been granted for this version to appear in e-Publications@Marquette. Elsevier does not grant permission for this article to be further copied/distributed or hosted elsewhere without the express permission from Elsevier. 
NOT THE PUBLISHED VERSION; this is the author's final, peer-reviewed manuscript. The published version may be accessed by following the link in the citation at the bottom of the page.

20. Tanaka H, Terada SJ. Therm Anal 1993;39:1011.

21. Cheary RW, Coelho AA. Programs XFIT and FOURYA, deposited in CCP14. Powder Diffraction Library, Engineering and Physical Sciences Research Council, Daresbury Laboratory, Warrington, England; 1996. <http://www.ccpI4.ac.ukltutorial/xfit-95/xfit.htm>.

22. Powder diffraction file alphabetical indexes. Inorganic phases. Swartmore, PA: JCPDS, International Centre for Diffraction Data; 1999.

23. Gilman JW, Kashiwagi T, Nyden M, Brown JET, Jackson CL, Lomakin $S$, et al. In: AI-Maliaka S, Golovoy A, Wilkie CA, editors. Chemistry and technology of polymer additives. London: Blackwell Scientific; 1999. p. 249-65.

24. Kandare E, Chigwada G, Wang D, Wilkie CA, Hossenlopp JM. Submitted for publication.

25. Green J. In: Grand AF, Wilkie CA, editors. Fire retardancy of polymeric materials. Marcel Dekker, Inc.; 2000. p. 147-70.

26. Pike RD, Starnes WH, Jeng JP, Bryant WS, Kourtesis P, Adams CW, et al. Macromolecules 1997;30:6957.

27. Shriver DF, Atkins $\mathrm{P}$, Langford $\mathrm{CH}$. Inorganic chemistry. 2nd ed. New York: Freeman;1994. p. 295.

28. Starnes WH, Pike RD, Cole JR, Doyal AS, Kimlin EJ, Lee JT, et al. Polym Degrad Stab 2003;82: 15.

29. Masciocchi N, Corradi E, Sironi A, Moretti G, Minelli G, Porta PJ. Solid State Chern 1997;131:252.

30. Wang Z, Qu B, Fan W, Huang PJ. Appl Polym Sci 2001;81:206.

\section{About the Authors}

Jeanne M. Hossenlopp: Department of Chemistry, Marquette University, P.O. Box 1881, Milwaukee, WI 53201-1881, USA

Tel.: +1 4142883537; fax: +14142887066

Email: jeanne.hossenlopp@mu.edu

Polymer Degradation and Stability, Vol. 91, No. 6 (June 2006): pg. 1209-1218. DOI. This article is (C) Elsevier and permission has been granted for this version to appear in e-Publications@Marquette. Elsevier does not grant permission for this article to be further copied/distributed or hosted elsewhere without the express permission from Elsevier. 
NOT THE PUBLISHED VERSION; this is the author's final, peer-reviewed manuscript. The published version may be accessed by following the link in the citation at the bottom of the page.

\section{Appendix}

Table 1: TGA Data for PVE Composites with CHDS, RDP and Cloisite 15A

\begin{tabular}{llllll}
\hline Sample & $T_{10}$ & $T_{50}$ & $\Delta T_{50}$ & $T_{\max }$ & Char (\%) \\
\hline PVE & $410 \pm 0$ & $444 \pm 0$ & 0 & $452 \pm 0$ & $7 \pm 0$ \\
PVE/RDP-5 & $390 \pm 1$ & $424 \pm 1$ & $-20 \pm 1$ & $415 \pm 2$ & $15 \pm 0(7.4)$ \\
PVE/RDP-10 & $369 \pm 2$ & $409 \pm 2$ & $-35 \pm 2$ & $400 \pm 1$ & $17 \pm 0(7.8)$ \\
PVE/RDP-15 & $376 \pm 1$ & $401 \pm 1$ & $-43 \pm 1$ & $390 \pm 0$ & $15 \pm 2(8.2)$ \\
PVE/15A-5 & $393 \pm 1$ & $440 \pm 1$ & $-4 \pm 1$ & $443 \pm 1$ & $11 \pm 0(9.7)$ \\
PVE/15A-10 & $383 \pm 1$ & $438 \pm 2$ & $-6 \pm 2$ & $432 \pm 2$ & $12 \pm 2(12.3)$ \\
PVE/15A-15 & $383 \pm 0$ & $434 \pm 0$ & $-10 \pm 0$ & $431 \pm 1$ & $17 \pm 0(15.0)$ \\
PVE/CHDS-5 & $385 \pm 1$ & $441 \pm 1$ & $-3 \pm 1$ & $450 \pm 2$ & $13 \pm 0(9.7)$ \\
PVE/CHDS-10 & $284 \pm 6$ & $440 \pm 1$ & $-4 \pm 1$ & $440 \pm 1$ & $18 \pm 2(12.3)$ \\
PVE/CHDS-15 & $306 \pm 2$ & $441 \pm 1$ & $-3 \pm 1$ & $444 \pm 1$ & $18 \pm 0(15.0)$ \\
PVE/CHDS/15A-5/5 & $332 \pm 6$ & $439 \pm 0$ & $-5 \pm 0$ & $444 \pm 2$ & $15 \pm 1(12.3)$ \\
PVE/CHDS/15A-5/10 & $337 \pm 2$ & $435 \pm 0$ & $-9 \pm 0$ & $438 \pm 2$ & $16 \pm 1(15.0)$ \\
PVE/CHDS/RDP-5/5 & $368 \pm 1$ & $419 \pm 0$ & $-25 \pm 0$ & $417 \pm 0$ & $19 \pm 1(10.1)$ \\
PVE/CHDS/RDP-5/10 & $300 \pm 2$ & $400 \pm 1$ & $-44 \pm 1$ & $389 \pm 1$ & $25 \pm 0(10.4)$ \\
\hline
\end{tabular}

$T 10$, Temperature at which $10 \%$ mass loss occurs; 750 , temperature at which $50 \%$ mass loss occurs; $\triangle T 50, T 50$ (composite) - T50 (pure PVE); Tmax, temperature at maximum degradation rate. Italicized entries are the expected char based on the residue obtained from pure PVE, CHDS and/or Cloisite 15A fractions.

Table 2: Cone calorimetry data for PVE composites with CHDS, RDP, and Cloisite 15A

\begin{tabular}{|c|c|c|c|c|c|c|}
\hline Sample & $\operatorname{TSC}(\mathrm{s})$ & $\begin{array}{c}\mathrm{PHRR}\left(\mathrm{kW} / \mathrm{m}^{2}\right) \\
(\% \text { reduction })\end{array}$ & $\begin{array}{l}\text { THR }\left(\mathrm{MJ} / \mathrm{m}^{2}\right) \\
\text { (\% reduction) }\end{array}$ & $\operatorname{AMLR}\left(\mathrm{g} / \mathrm{stm}^{2}\right)$ & $\mathrm{CY}(\%)$ & $\operatorname{ASEA}\left(\mathrm{m}^{2} / \mathrm{kg}\right)$ \\
\hline PVE & $65 \pm 9$ & $895 \pm 67$ & $71 \pm 1$ & $27 \pm 1$ & $3.9 \pm 0.2$ & $1089 \pm 88$ \\
\hline PVE/RDP-5 & $58 \pm 3$ & $613 \pm 83(32)$ & $59 \pm 2(25)$ & $24 \pm 2$ & $7.2 \pm 0.4$ & $1175 \pm 16$ \\
\hline PVE/RDP-10 & $62 \pm 3$ & $546 \pm 18(40)$ & $55 \pm 6(31)$ & $25 \pm 2$ & $8.0 \pm 0.2$ & $1495 \pm 19$ \\
\hline PVE/RDP-15 & $61 \pm 4$ & $578 \pm 66(35)$ & $53 \pm 2(33)$ & $26 \pm 1$ & $8.6 \pm 0.2$ & $1488 \pm 84$ \\
\hline $\mathrm{PVE} / 15 \mathrm{~A}-5$ & $51 \pm 5$ & $832 \pm 82(7)$ & $71 \pm 1(8)$ & $26 \pm 2$ & $5.9 \pm 0.8$ & $1048 \pm 16$ \\
\hline $\mathrm{PVE} / 15 \mathrm{~A}-10$ & $53 \pm 3$ & $562 \pm 20(37)$ & $70 \pm 1(11)$ & $20 \pm 3$ & $7.3 \pm 0.4$ & $1029 \pm 10$ \\
\hline$P V E / 15 A-15$ & $53 \pm 6$ & $636 \pm 22(29)$ & $72 \pm 3(9)$ & $18 \pm 1$ & $12.0 \pm 0.2$ & $1020 \pm 8$ \\
\hline PVE/CHDS-5 & $28 \pm 6$ & $879 \pm 56(6)$ & $64 \pm 1(18)$ & $28 \pm 1$ & $8.1 \pm 0.3$ & $1021 \pm 40$ \\
\hline PVE/CHDS-10 & $26 \pm 3$ & $853 \pm 18(5)$ & $58 \pm 1(27)$ & $27 \pm 2$ & $11.8 \pm 0.2$ & $948 \pm 21$ \\
\hline PVE/CHDS-15 & $21 \pm 0$ & $553 \pm 28(38)$ & $68 \pm 2(14)$ & $17 \pm 2$ & $10.5 \pm 0.1$ & $1013 \pm 31$ \\
\hline $\mathrm{PVE} / \mathrm{CHDS} / 15 \mathrm{~A}-5 / 5$ & $30 \pm 8$ & $719 \pm 50(2)$ & $70 \pm 4(11)$ & $24 \pm 1$ & $8.7 \pm 0.3$ & $1025 \pm 2$ \\
\hline PVE/CHDS/15A-5/10 & $23 \pm 4$ & $567 \pm 41(36)$ & $64 \pm 2(18)$ & $17 \pm 1$ & $12.5 \pm 0.6$ & $1064 \pm 26$ \\
\hline PVE/CHDS/RDP-5/5 & $29 \pm 2$ & $844 \pm 77(6)$ & $62 \pm 1(22)$ & $29 \pm 1$ & $11.9 \pm 0.3$ & $1068 \pm 55$ \\
\hline PVE/CHDS/RDP-5/10 & $32 \pm 8$ & $739 \pm 97(15)$ & $44 \pm 5(47)$ & $28 \pm 1$ & $13.8 \pm 1.2$ & $953 \pm 46$ \\
\hline
\end{tabular}

TSC, Time to sustained combustion; PHRR, peak heat release rate (\% reduction); THR, total heat release (\% reduction); AMLR, average mass loss rate; $\mathrm{CY}$, char\%; ASEA, average specific extinction area (a measure of smoke).

Polymer Degradation and Stability, Vol. 91, No. 6 (June 2006): pg. 1209-1218. DOI. This article is (C) Elsevier and permission has been granted for this version to appear in e-Publications@Marquette. Elsevier does not grant permission for this article to be further copied/distributed or hosted elsewhere without the express permission from Elsevier. 


\section{Figure 1}

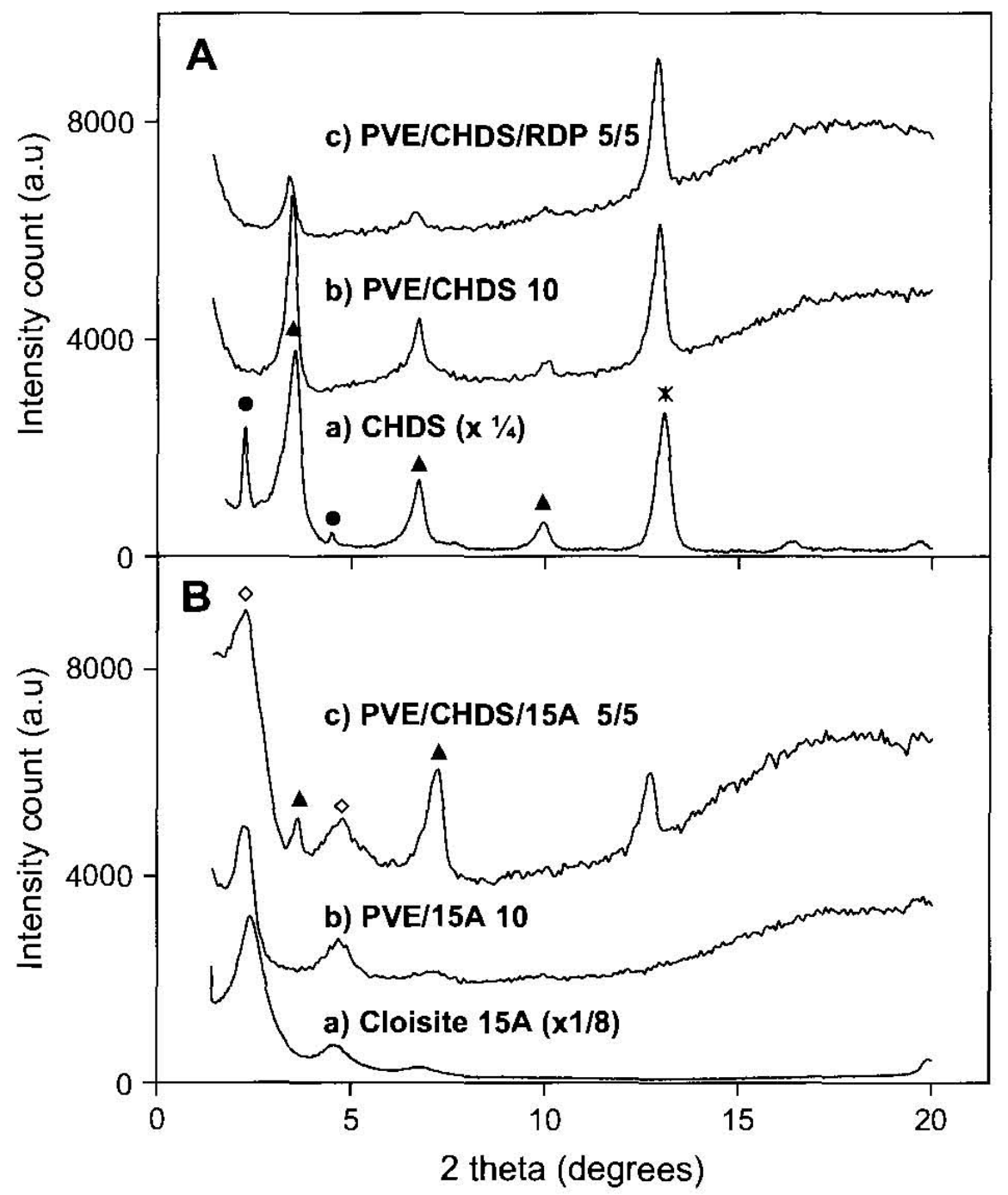

(a) XRD data for (a) partially exchanged CHDS revealing the presence of two phases; $(\bullet)$ with basal spacing, $d=39.2 \AA$ and $(\boldsymbol{\Delta})$ with $d=25.9 \AA$; reflections from the precursor, CHN $(*)$ observed, (b) PEV/CHDS-10, and (c) PVE/CHDS/RDP$5 / 5$. The XRD of the partially exchanged CHDS is scaled by a factor of $1 / 4$.

(B) XRD data for (a) Cloisite 15A, (b) PVE/15A-10, and (c) PVE/CHDS/15A-5/5. Cloisite $15 A$ data in trace $a$ is scaled by a factor of $1 / 8$. In trace $c$ both CHDS $(\boldsymbol{\Delta})$ and Cloisite 15A $(\diamond)$ reflections are observed. Data are offset by clarity and not scaled unless mentioned otherwise.

Polymer Degradation and Stability, Vol. 91, No. 6 (June 2006): pg. 1209-1218. DOI. This article is (C) Elsevier and permission has been granted for this version to appear in e-Publications@Marquette. Elsevier does not grant permission for this article to be further copied/distributed or hosted elsewhere without the express permission from Elsevier. 
NOT THE PUBLISHED VERSION; this is the author's final, peer-reviewed manuscript. The published version may be accessed by following the link in the citation at the bottom of the page.

\section{Figure 2}
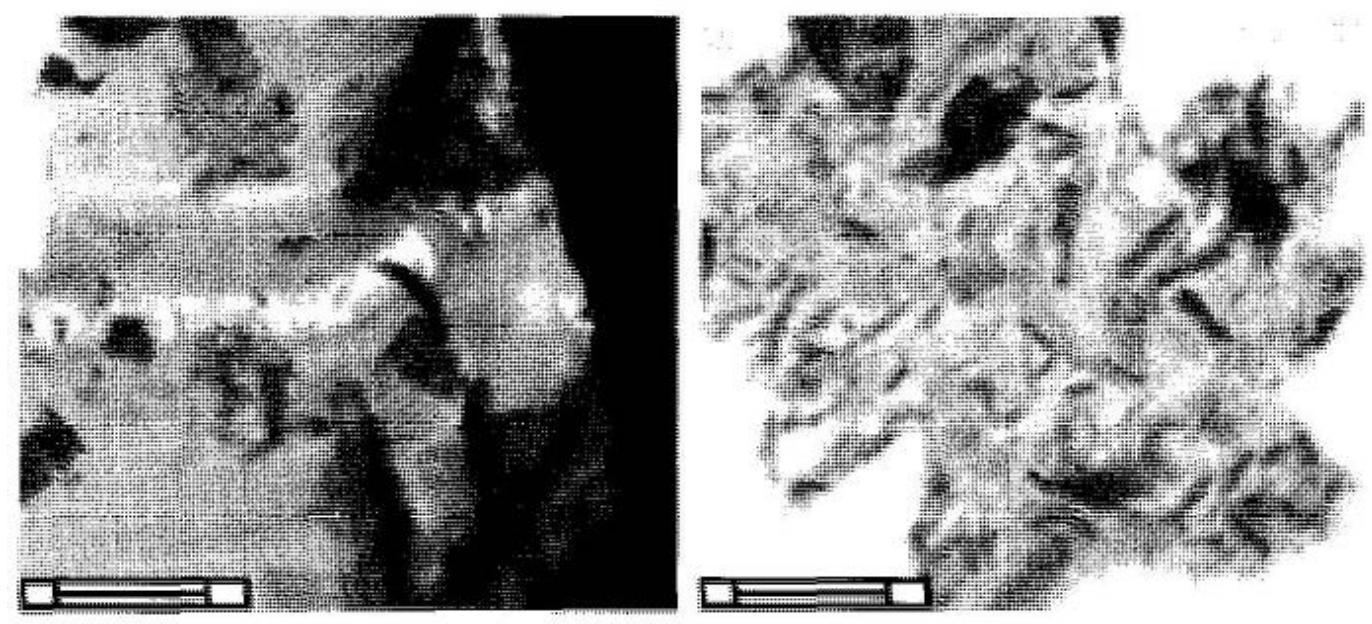

TEM images at low (left) and high (right) magnifications for PVE/CHDS/RDP-5/5. For low magnification the scale bar (bottom left) represents $500 \mathrm{~nm}$, while for high magnification the scale bar (bottom left) represents $100 \mathrm{~nm}$.

Polymer Degradation and Stability, Vol. 91, No. 6 (June 2006): pg. 1209-1218. DOI. This article is (C) Elsevier and permission has been granted for this version to appear in e-Publications@Marquette. Elsevier does not grant permission for this article to be further copied/distributed or hosted elsewhere without the express permission from Elsevier. 


\section{Figure 3}

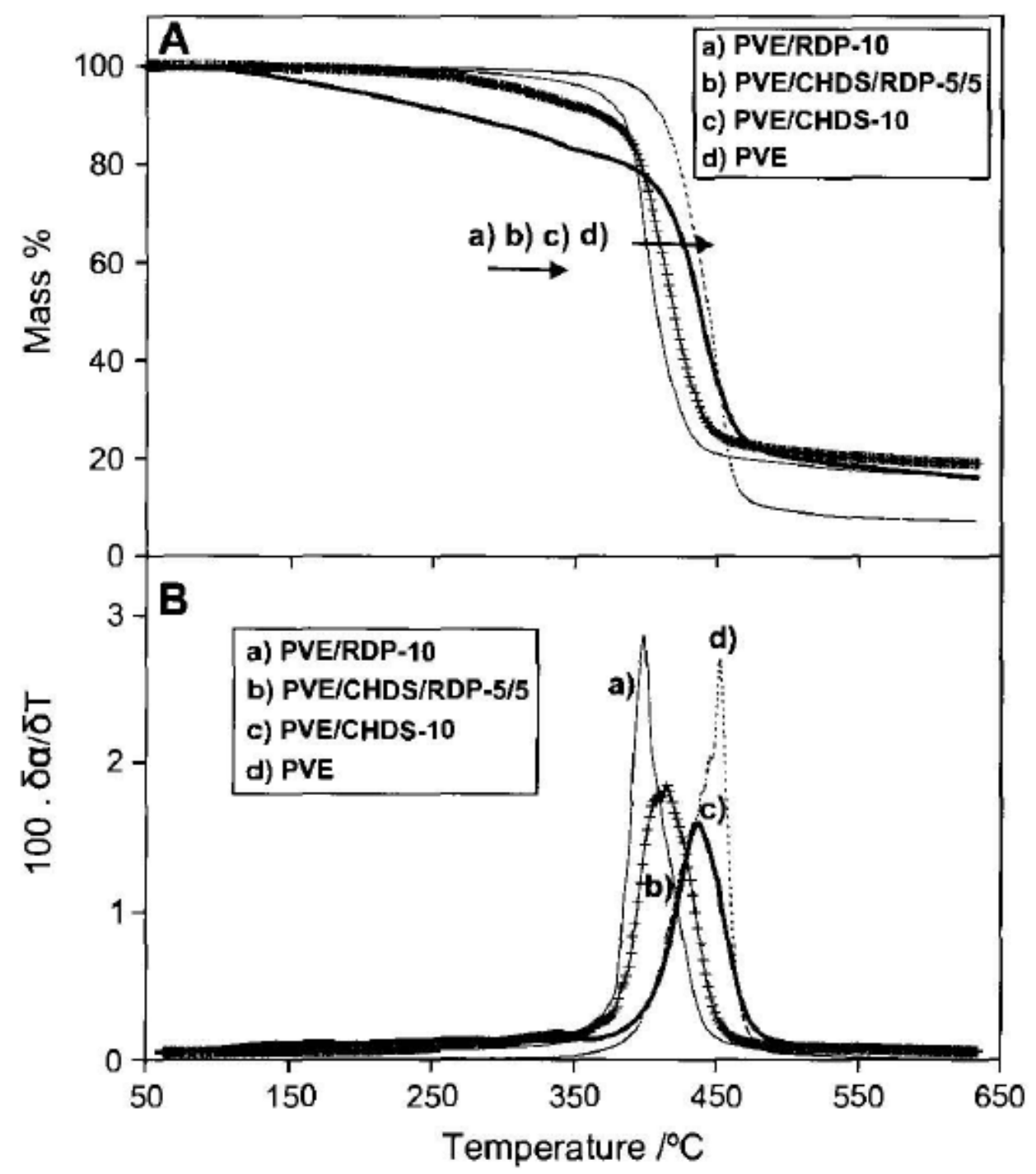

(A) TGA curves for (a) PVE/RDP-10 (solid), (b) PVE/CHDS/RDP-5/5 (hatched), (c) PVE/CHDS-10 (bold), and (d) pure PVE (dashed).

(B) DTG curves for (a) PVE/RDP-10 (solid), (b) PVE/CHDS/RDP-5/5 (hatched), (c) PVE/CHDS-10 (solid), and (d) pure PVE (dashed). Derivatized mass losses are scaled by a factor of 100 . 
NOT THE PUBLISHED VERSION; this is the author's final, peer-reviewed manuscript. The published version may be accessed by following the link in the citation at the bottom of the page.

Figure 4

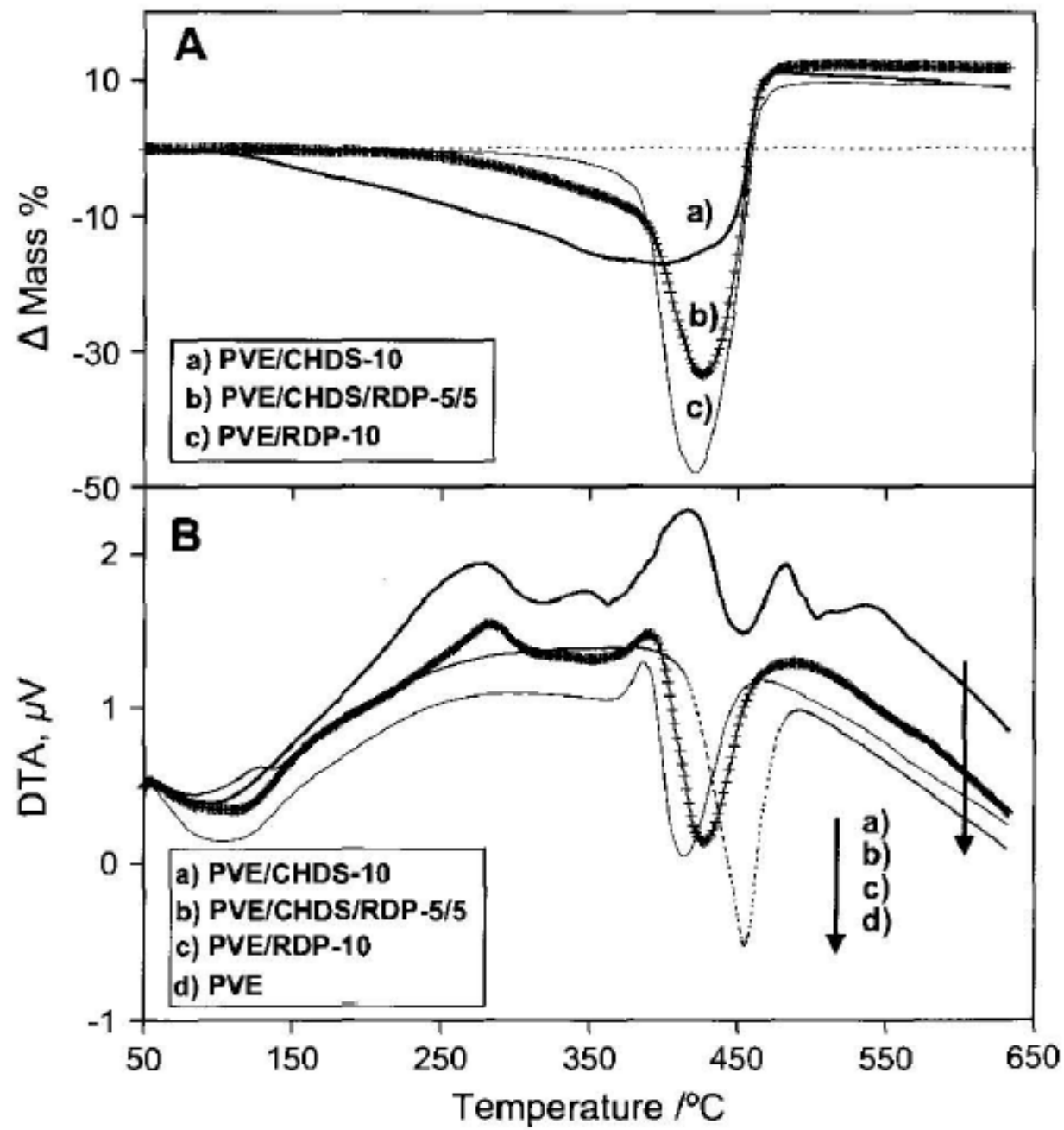

(A) Curves of mass loss differences for PVE composites (a) PVE/CHDS-10 (bold), (b) PVE/CHDS/RDP-5/5 (hatched), and (c) PVE/RDP-10 (solid) as a function of degradation temperature.

(B) DTA curves for (a) PVE/CHDS-10 (bold), (b) PVE/CHDS/RDP-5/5 (hatched), (c) PVE/RDP-10 (solid), and (d) pure PVE (dashed).

Polymer Degradation and Stability, Vol. 91, No. 6 (June 2006): pg. 1209-1218. DOI. This article is (C) Elsevier and permission has been granted for this version to appear in e-Publications@Marquette. Elsevier does not grant permission for this article to be further copied/distributed or hosted elsewhere without the express permission from Elsevier. 
NOT THE PUBLISHED VERSION; this is the author's final, peer-reviewed manuscript. The published version may be accessed by following the link in the citation at the bottom of the page.

\section{Figure 5}

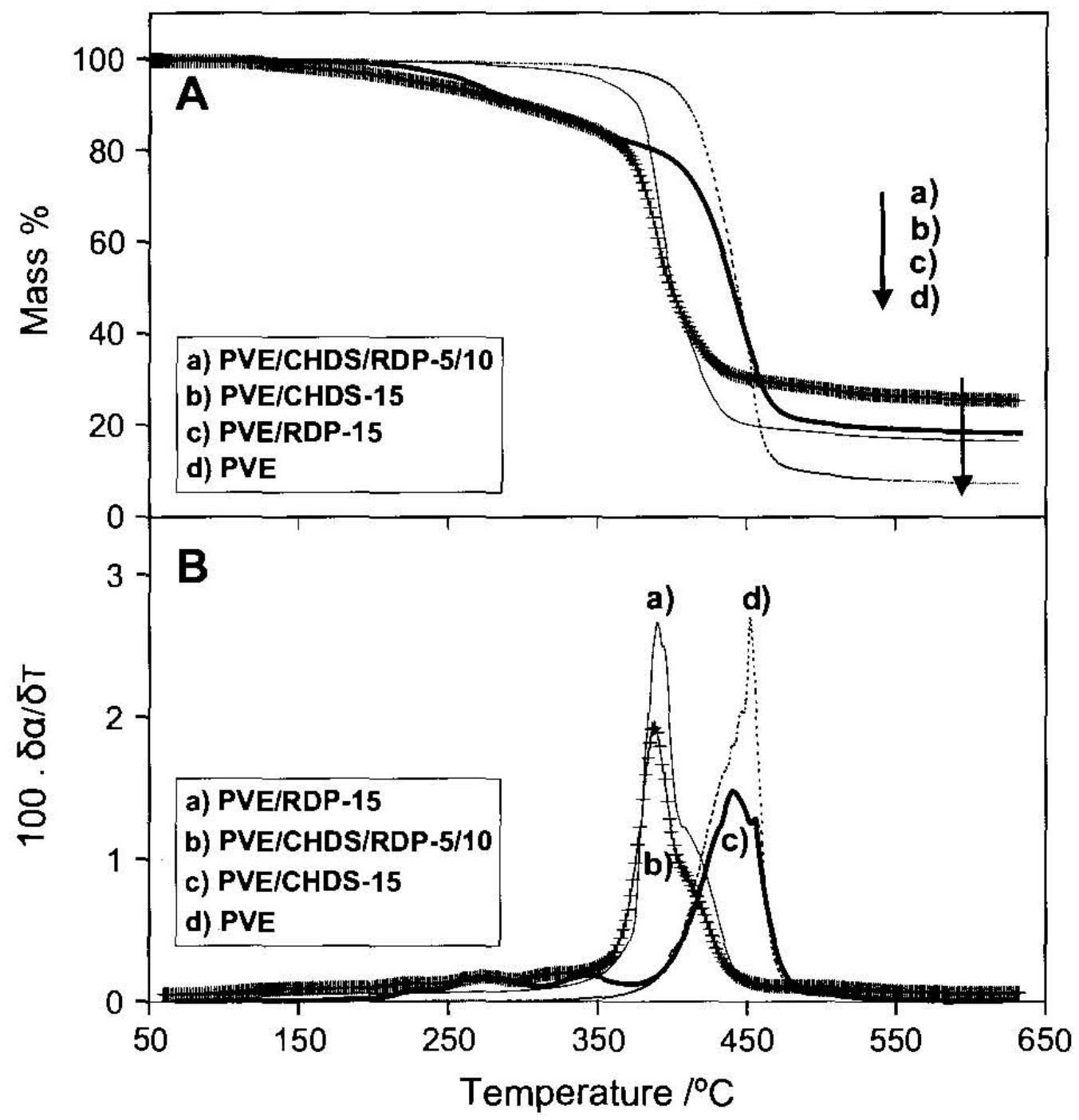

(A) TGA curves for (a) PVE/CHDS/RDP-5/10 (hatched), (b) PVE/CHDS-15 (bold), (c) PVE/RDP-15 (solid), and (d) pure PVE (dashed).

(B) DTG curves for (a) PVE/RDP-15 (solid), (b) PVE/CHDS/RDP-5/10 (hatched), (c) PVE/CHDS-15 (bold), and (d) pure PVE (dashed). Derivatized mass losses are scaled by a factor of 100 .

Polymer Degradation and Stability, Vol. 91, No. 6 (June 2006): pg. 1209-1218. DOI. This article is (C) Elsevier and permission has been granted for this version to appear in e-Publications@Marquette. Elsevier does not grant permission for this article to be further copied/distributed or hosted elsewhere without the express permission from Elsevier. 
NOT THE PUBLISHED VERSION; this is the author's final, peer-reviewed manuscript. The published version may be accessed by following the link in the citation at the bottom of the page.

Figure 6

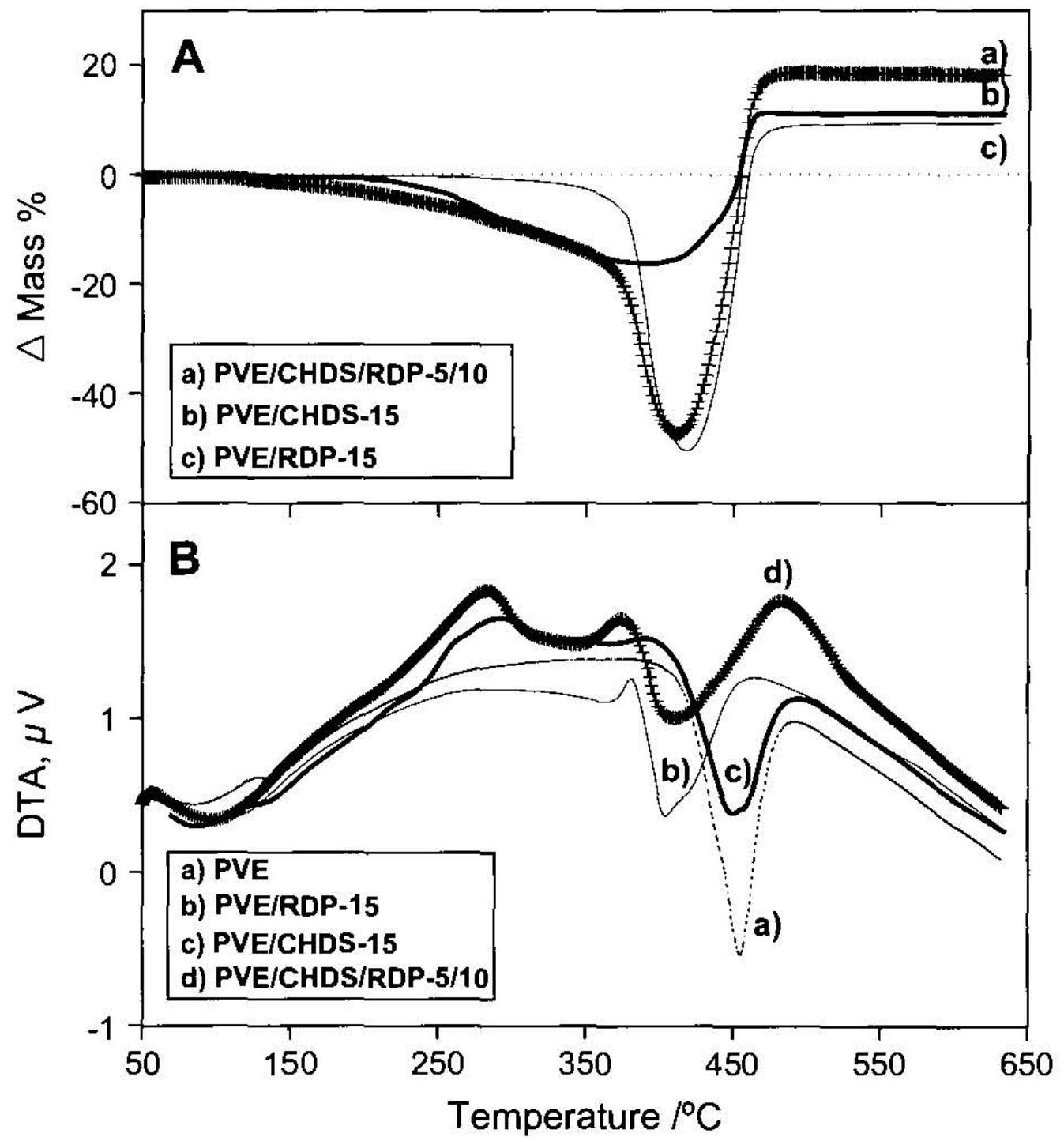

(A) Curves of mass loss differences for PVE composites (a) PVE/CHDS/RDP-5/10 (hatched), (b) PVE/CHDS-15 (bold), and (c) PVE/RDP-15 (solid) as a function of degradation temperature.

(B) DTA curves for (a) pure PVE (dashed), (b) PVE/RDP-15 (solid), (c) PVE/CHDS-15 (bold), and (d) PVE/CHDS/RDP-5/10 (hatched).

Polymer Degradation and Stability, Vol. 91, No. 6 (June 2006): pg. 1209-1218. DOI. This article is (C) Elsevier and permission has been granted for this version to appear in e-Publications@Marquette. Elsevier does not grant permission for this article to be further copied/distributed or hosted elsewhere without the express permission from Elsevier. 
NOT THE PUBLISHED VERSION; this is the author's final, peer-reviewed manuscript. The published version may be accessed by following the link in the citation at the bottom of the page.

Figure 7

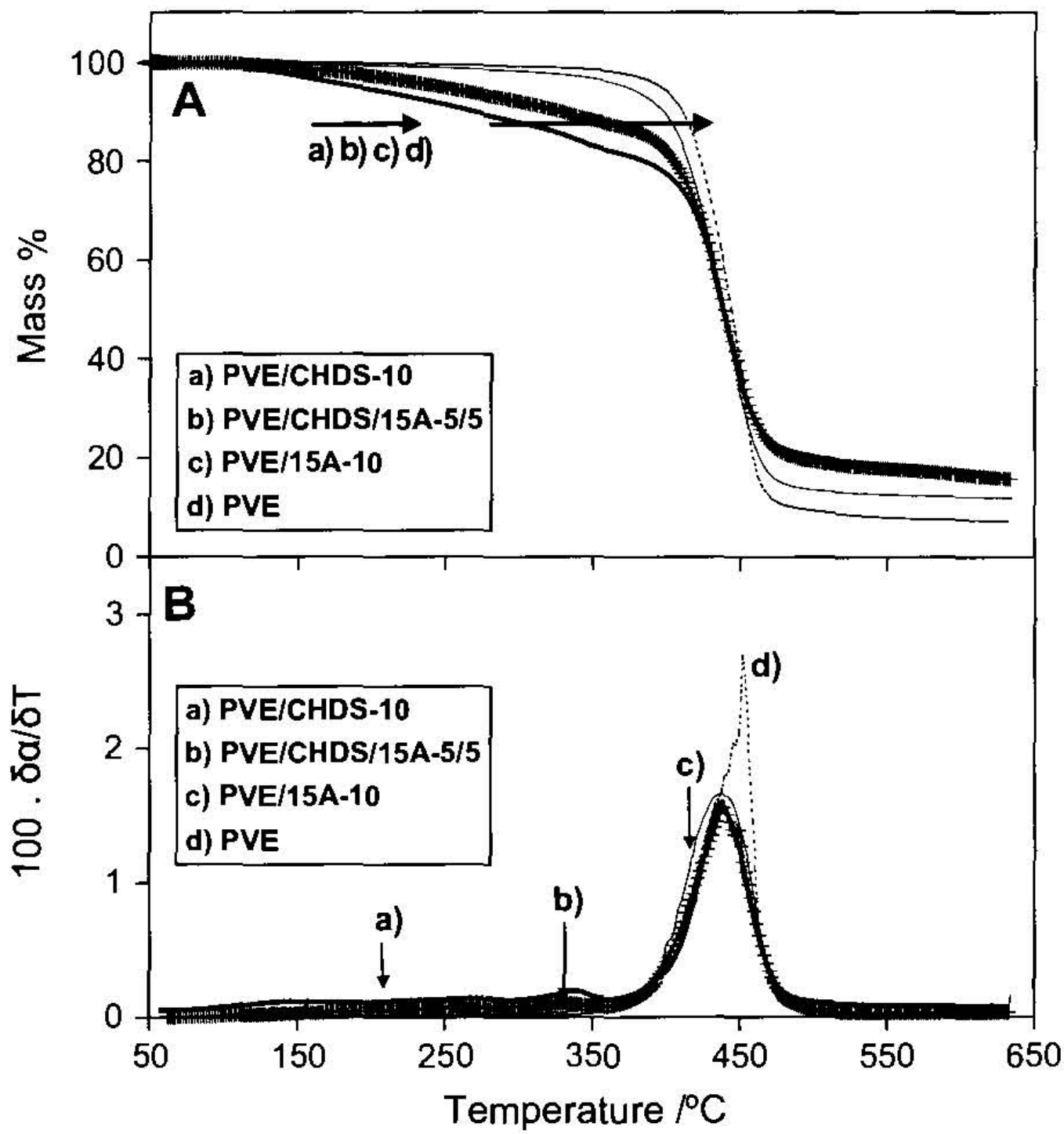

(A) TGA curves for (a) PVE/CHDS-10 (bold), (b) PVE/CHDS/15A-5/5 (hatched), (c) PVE/15A-10 (solid), and (d) pure PVE (dashed).

(B) DTG curves for (a) PVE/CHDS-10 (bold), (b) PVE/CHDS/15A-5/5 (hatched), (c) PVE/15A-10 (solid), and (d) pure PVE (dashed). Derivatized mass losses are scaled by a factor of 100.

Polymer Degradation and Stability, Vol. 91, No. 6 (June 2006): pg. 1209-1218. DOI. This article is (C) Elsevier and permission has been granted for this version to appear in e-Publications@Marquette. Elsevier does not grant permission for this article to be further copied/distributed or hosted elsewhere without the express permission from Elsevier. 
NOT THE PUBLISHED VERSION; this is the author's final, peer-reviewed manuscript. The published version may be accessed by following the link in the citation at the bottom of the page.

\section{Figure 8}

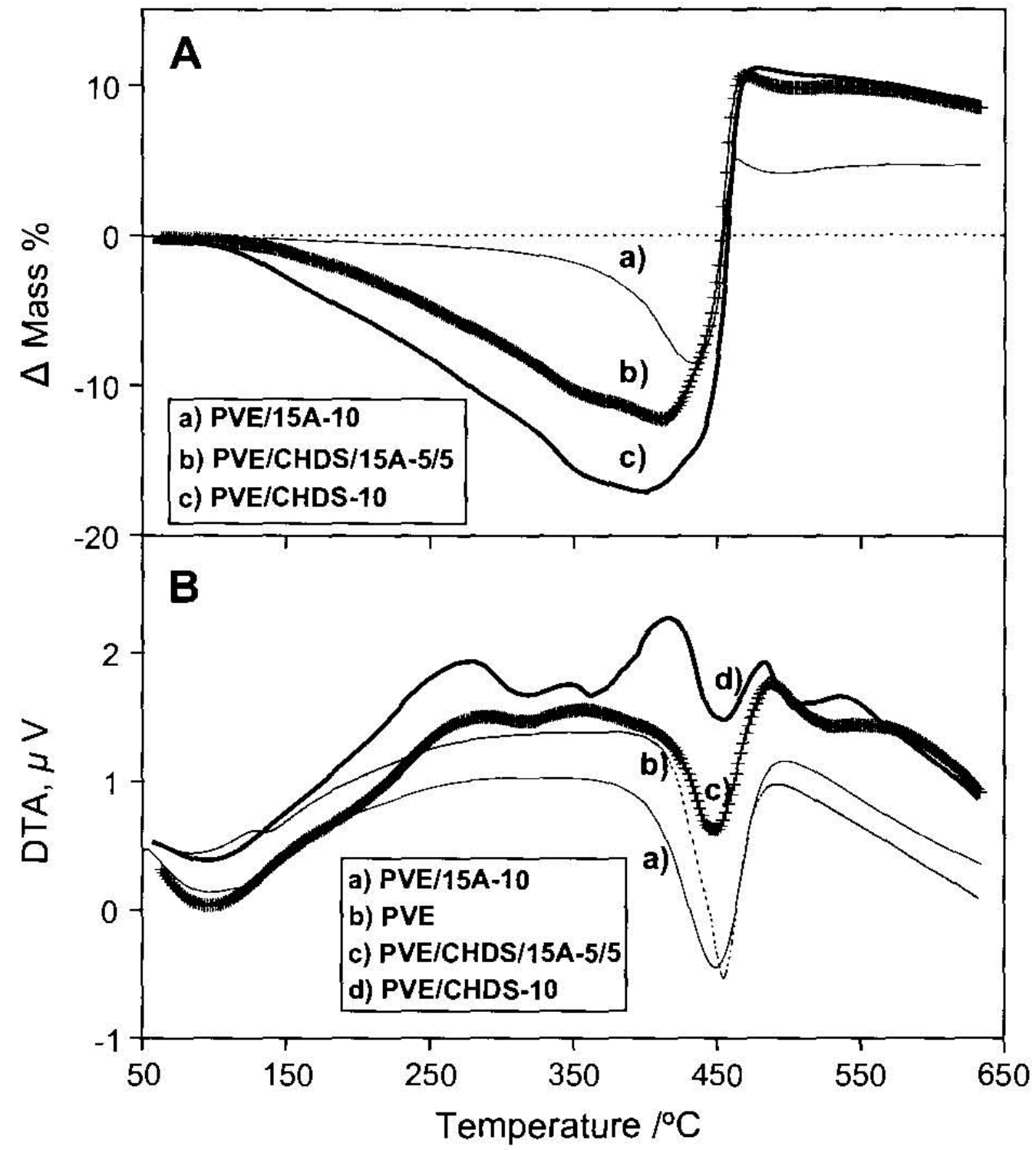

(A) Curves of mass loss differences for PVE composites (a) PVE/15A-10 (solid), (b) PVE/CHDS/15A-5/5 (hatched), and (c) PVE/CHDS-10 (bold) as a function of degradation temperature.

(B) DTA curves for (a) PVE/15A-10 (solid), (b) pure PVE (dashed), (c) PVE/CHDS/15A5/5 (hatched), and (d) PVE/CHDS-10 (bold).

Polymer Degradation and Stability, Vol. 91, No. 6 (June 2006): pg. 1209-1218. DOI. This article is (C) Elsevier and permission has been granted for this version to appear in e-Publications@Marquette. Elsevier does not grant permission for this article to be further copied/distributed or hosted elsewhere without the express permission from Elsevier. 


\section{Figure 9}

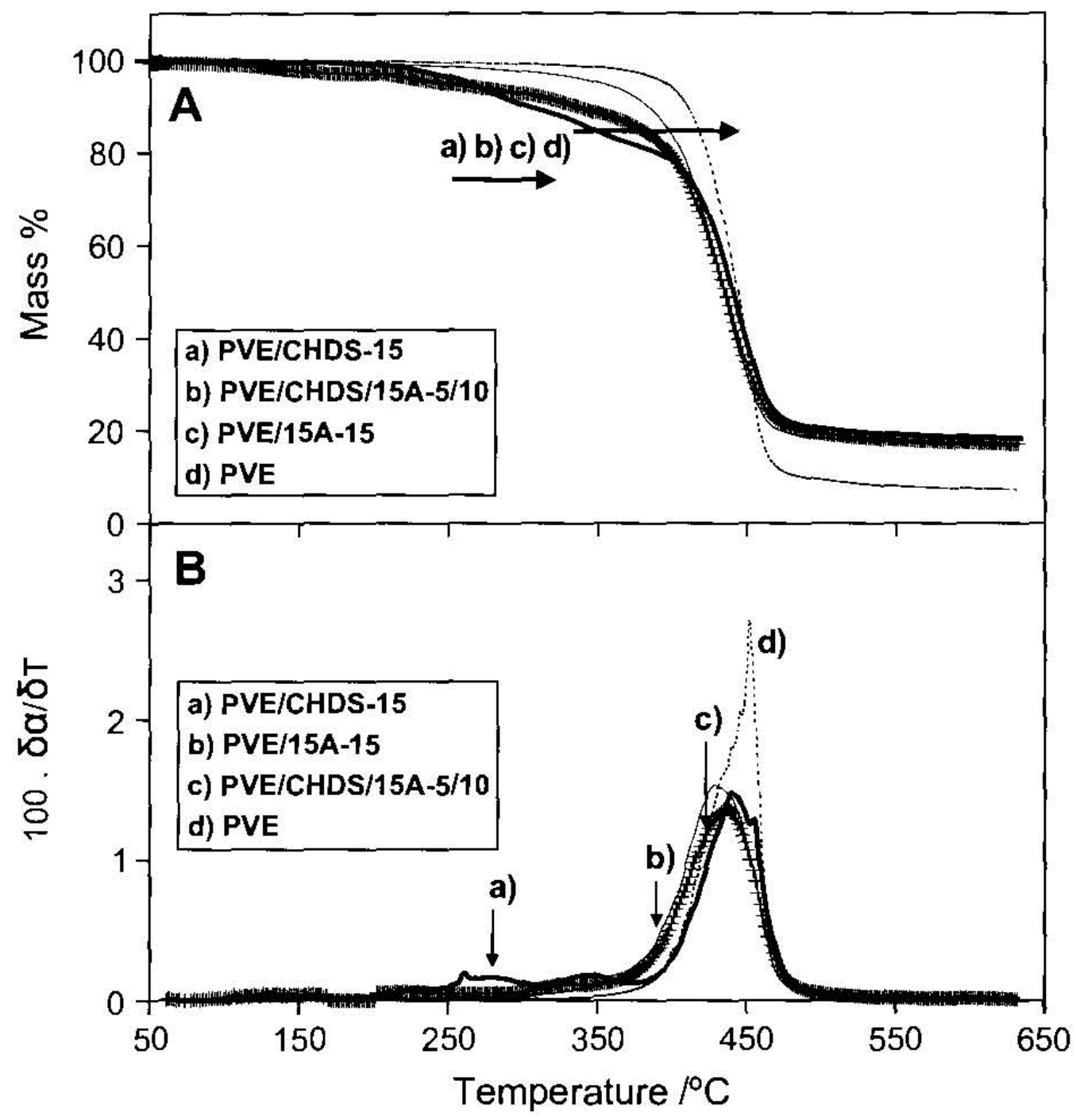

(A) TGA curves for (a) PVE/CHDS-15 (bold), (b) PVE/CHDS/15A-5/10 (hatched), (c) PVE/15A-15 (solid), and (d) pure PVE (dashed).

(B) DTG curves for (a) PVE/CHDS-15 (bold), (b) PVE/15A-15 (solid), (c) PVE/CHDS/15A-5/10 (hatched), and (d) pure PVE (dashed). Derivatized mass losses are scaled by a factor of 100 .

Polymer Degradation and Stability, Vol. 91, No. 6 (June 2006): pg. 1209-1218. DOI. This article is (C) Elsevier and permission has been granted for this version to appear in e-Publications@Marquette. Elsevier does not grant permission for this article to be further copied/distributed or hosted elsewhere without the express permission from Elsevier. 
NOT THE PUBLISHED VERSION; this is the author's final, peer-reviewed manuscript. The published version may be accessed by following the link in the citation at the bottom of the page.

Figure 10

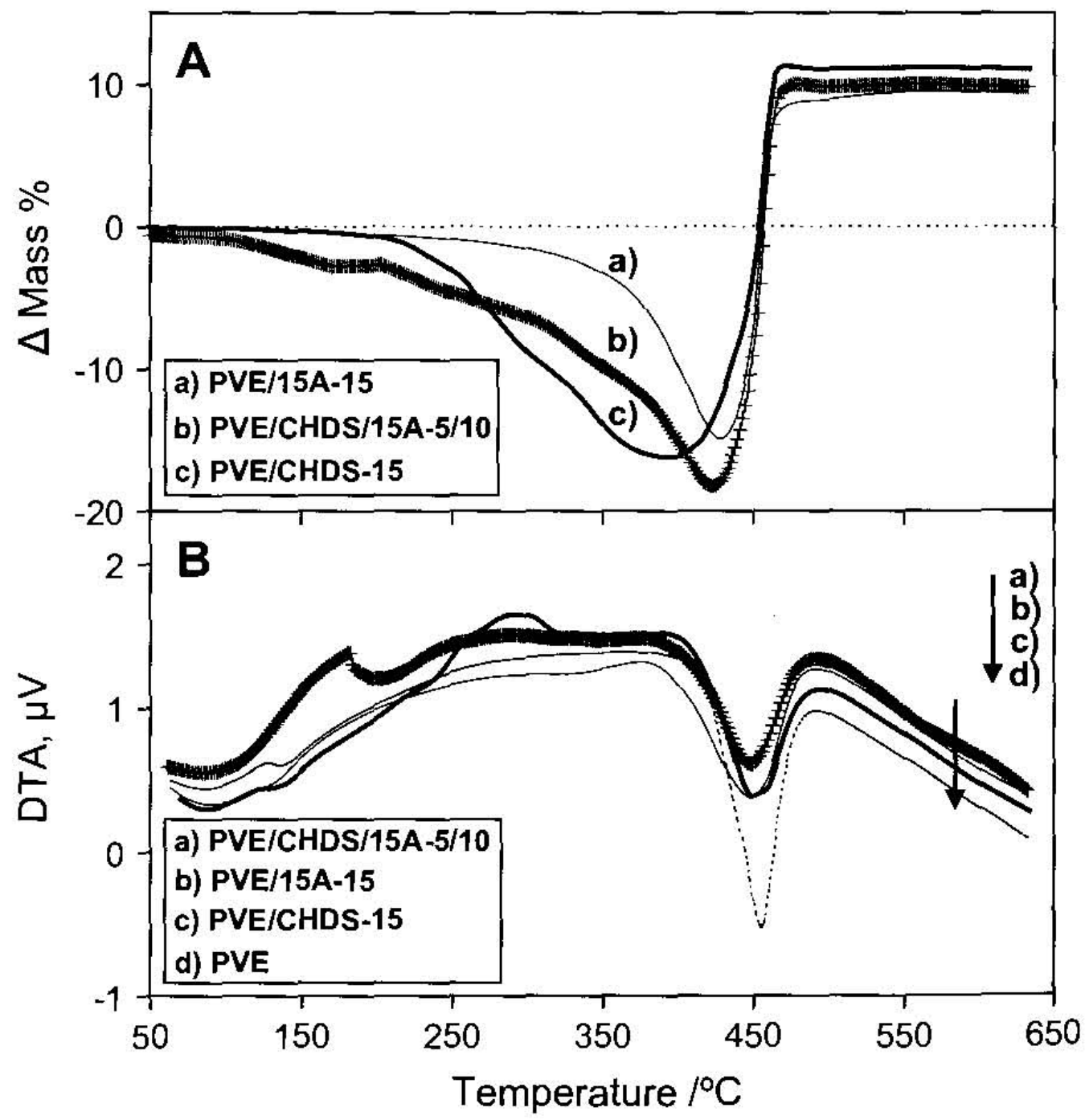

(A) Curves of mass loss differences for PVE composites (a) PVE/15A-15 (solid), (b) PVE/CHDS/15A-5/10 (hatched), and (c) PVE/CHDS-15 (bold) as a function of degradation temperature.

(B) DTA curves for (a) PVE/CHDS/15A-5/10 (hatched), (b) PVE/15A-15 (solid), (c) PVE/CHDS-15 (bold), and (d) pure PVE (dashed).

Polymer Degradation and Stability, Vol. 91, No. 6 (June 2006): pg. 1209-1218. DOI. This article is (C) Elsevier and permission has been granted for this version to appear in e-Publications@Marquette. Elsevier does not grant permission for this article to be further copied/distributed or hosted elsewhere without the express permission from Elsevier. 
Figure 11

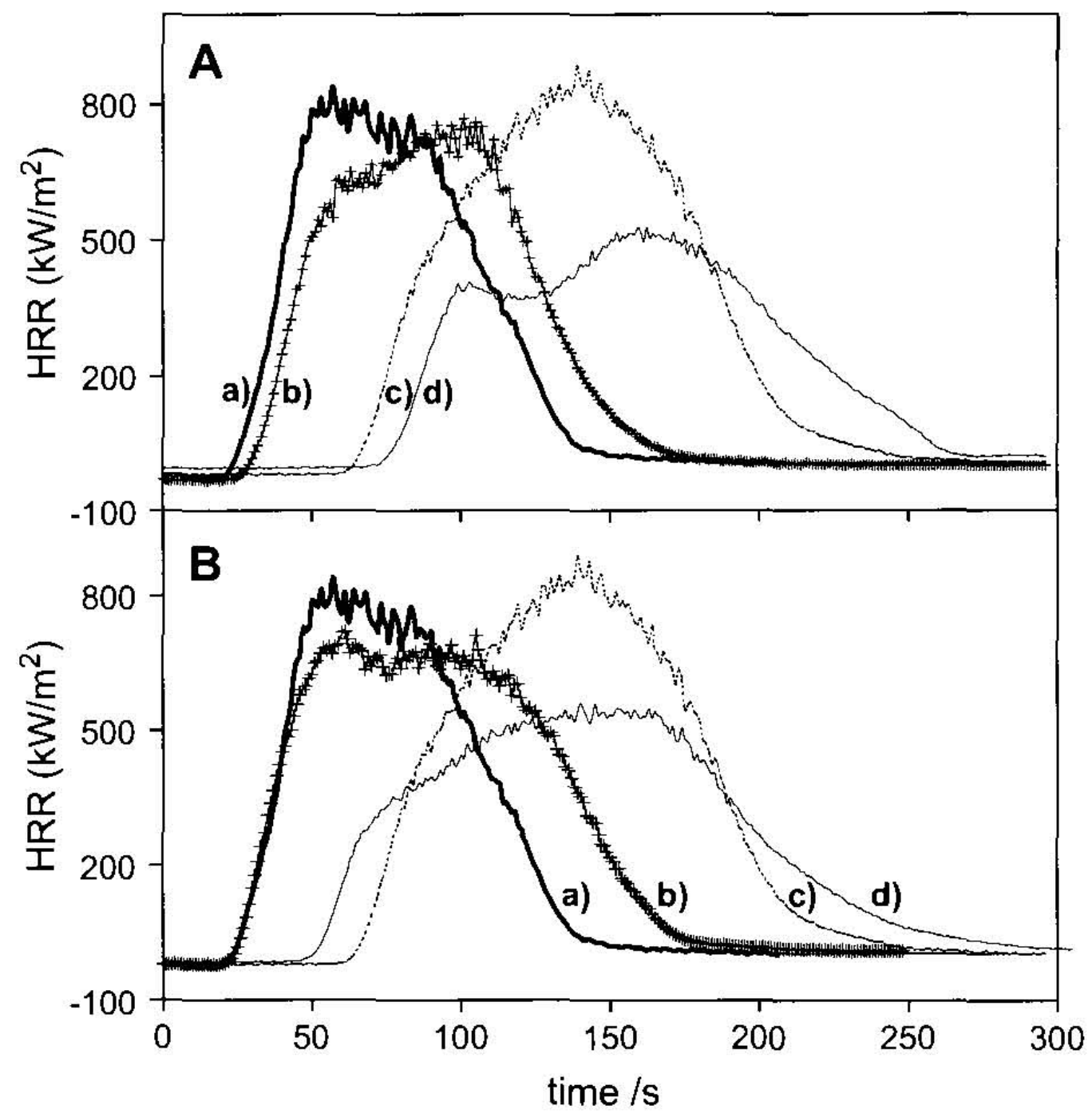

(A) Heat release rate curves for (a) PVE/CHDS-10 (bold), (b) PVE/CHDS/RDP-5/5 (hatched), (c) pure PVE (dashed), and (d) PVE/RDP-10 (solid) from cone calorimetry measurements at $35 \mathrm{~kW} / \mathrm{m} 2$.

(B) Heat release rate curves for (a) PVE/CHDS-10 (bold), (b) PVE/CHDS/15A-5/5 (hatched), (c) pure PVE (dashed), and (d) PVE/15A-10 (solid) from cone calorimetry measurements at $35 \mathrm{~kW} / \mathrm{m} 2$.

Polymer Degradation and Stability, Vol. 91, No. 6 (June 2006): pg. 1209-1218. DOI. This article is (C) Elsevier and permission has been granted for this version to appear in e-Publications@Marquette. Elsevier does not grant permission for this article to be further copied/distributed or hosted elsewhere without the express permission from Elsevier. 
NOT THE PUBLISHED VERSION; this is the author's final, peer-reviewed manuscript. The published version may be accessed by following the link in the citation at the bottom of the page.

Figure 12

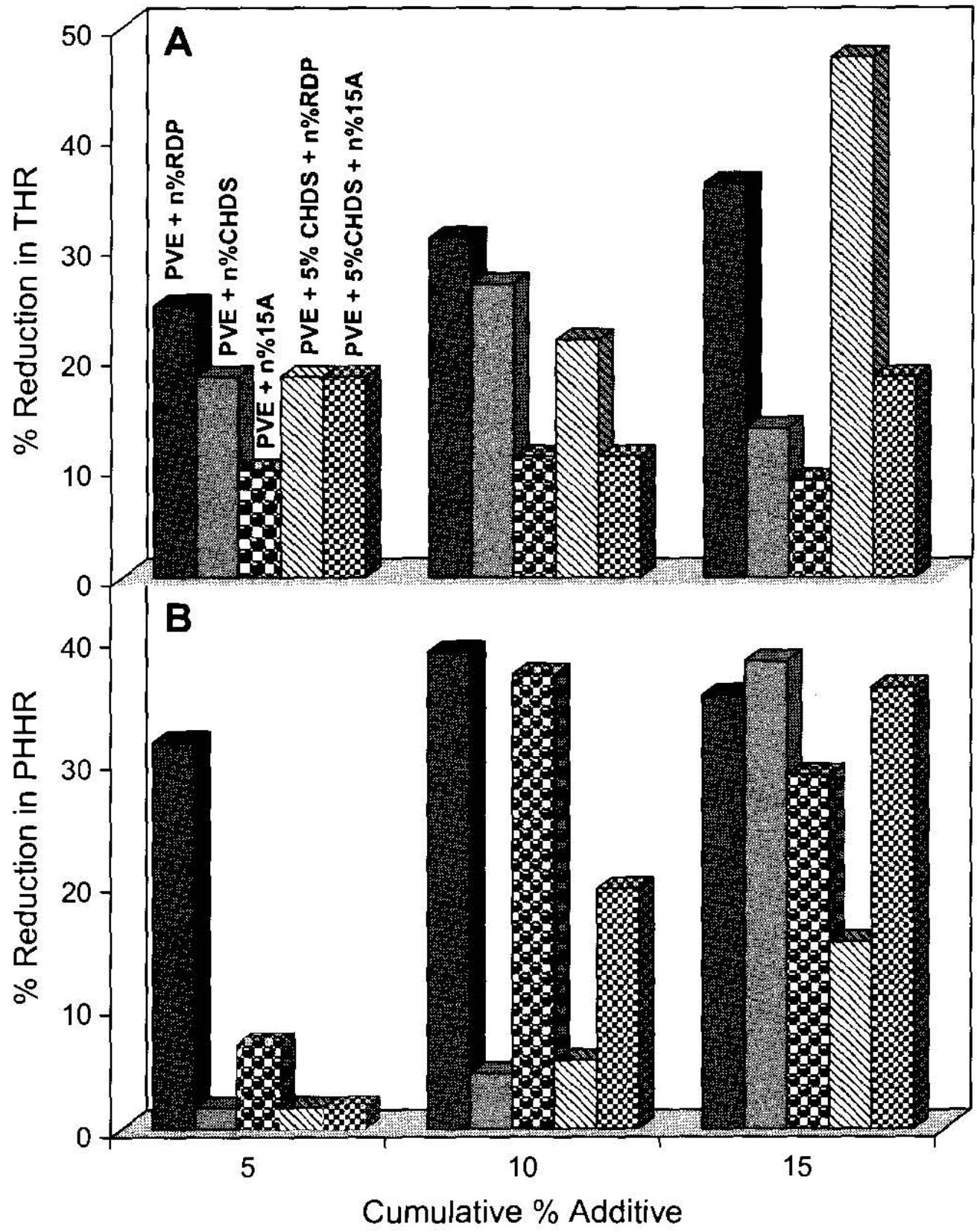

(A) Percent reduction in total heat release (THR) vs. \% additive for all composites.

(B) Percent reduction in peak heat release (PHRR) vs. \% additive for all composites.

Polymer Degradation and Stability, Vol. 91, No. 6 (June 2006): pg. 1209-1218. DOI. This article is (C) Elsevier and permission has been granted for this version to appear in e-Publications@Marquette. Elsevier does not grant permission for this article to be further copied/distributed or hosted elsewhere without the express permission from Elsevier. 


\section{Figure 13}

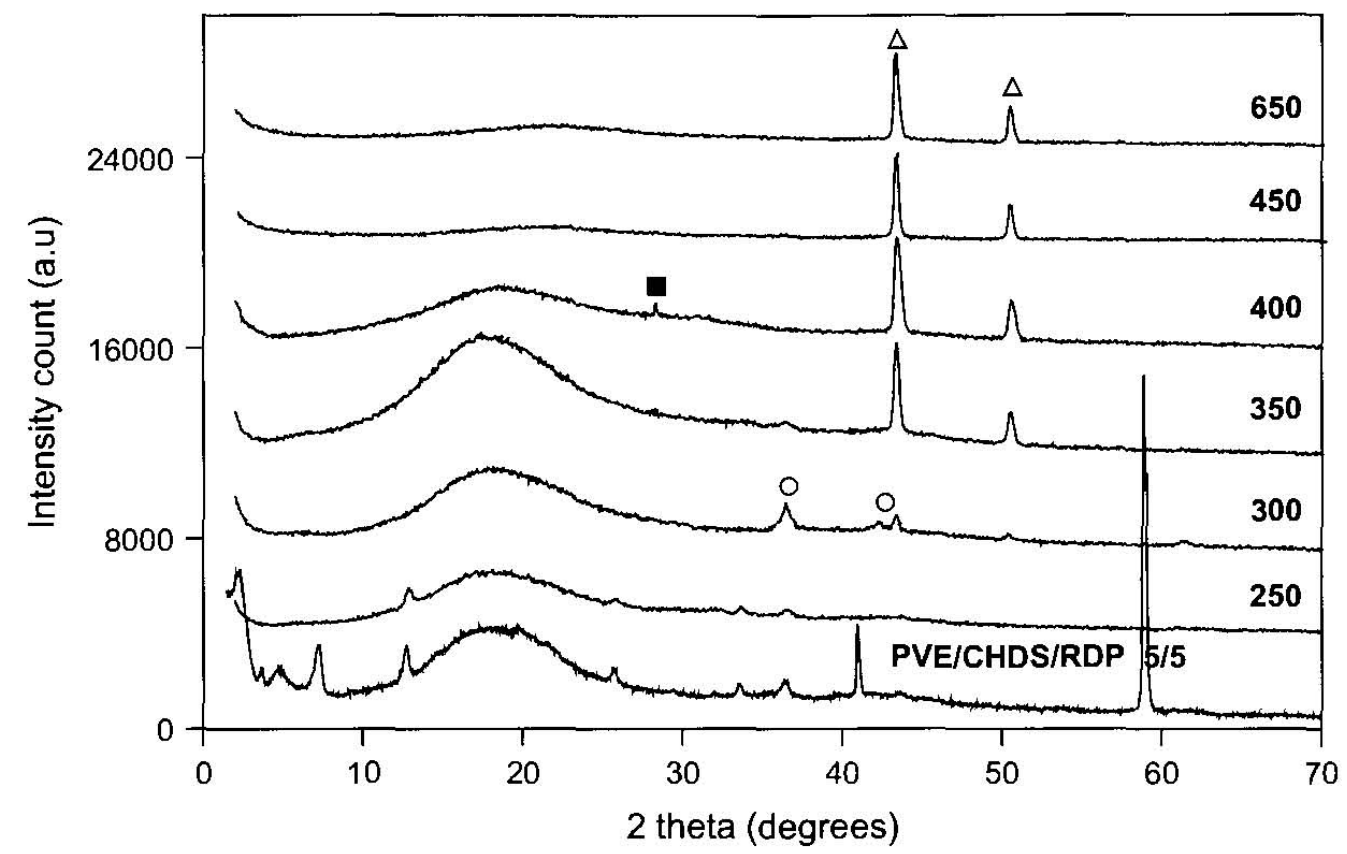

XRD pattern of PVE/CHDS/RDP-5/5 and its residues after heating to indicated temperatures $\left(250,300,350,400,450\right.$, and $\left.650^{\circ} \mathrm{C}\right)$ at $20^{\circ} \mathrm{C} / \mathrm{min}$ in TGA. $\mathrm{Cu}(\Delta)$, Cu2O (0), and an unidentified phase $(-)$ are revealed in the XRD patterns of the residues. Data are offset for clarity but otherwise not scaled. 
NOT THE PUBLISHED VERSION; this is the author's final, peer-reviewed manuscript. The published version may be accessed by following the link in the citation at the bottom of the page.

\section{Figure 14}

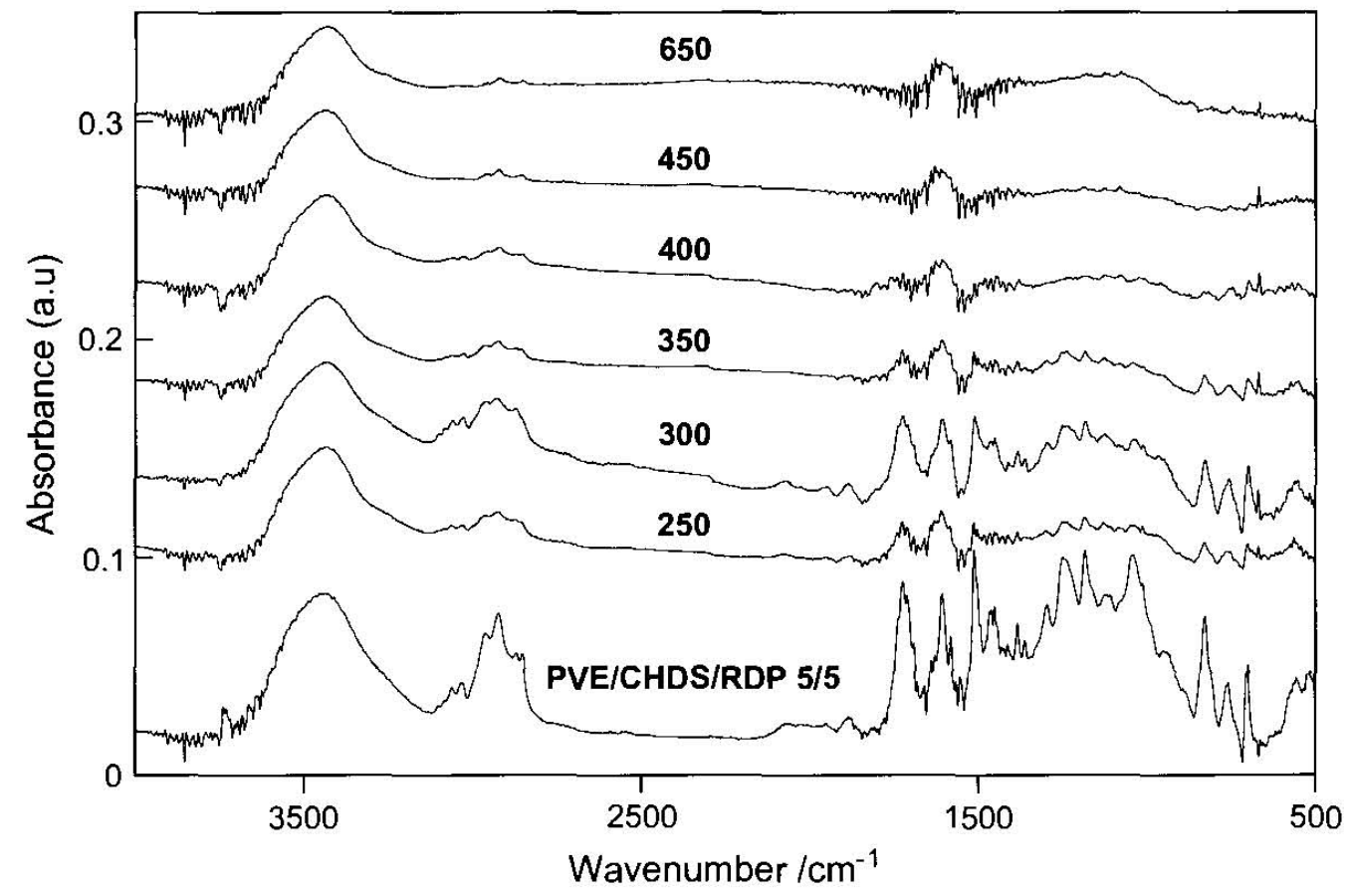

Fourier transform infrared (FTIR) traces for PVE/CHDS/RDP-5/5 and TGA residues of PVE/CHDS/RDP-5/5 heated to different temperatures indicated in the plot. Data are offset for clarity but otherwise not scaled. 